OPEN ACCESS

Edited by:

David M. Ojcius,

University of the Pacific, United States

Reviewed by:

Balgis Gaffar,

Imam Abdulrahman Bin Faisal

University, Saudi Arabia

Anas Salami,

Mohammed Bin Rashid University of

Medicine and Health Sciences, United

Arab Emirates

*Correspondence:

Filippo Zanett

filippo.zanetti@mi.com

${ }^{\dagger}$ These authors have contributed equally to this work

Specialty section:

This article was submitted to Oral Health Promotion,

a section of the journal

Frontiers in Oral Health

Received: 15 September 2021 Accepted: 15 November 2021 Published: 10 December 2021

Citation:

Zanetti F, Zivkovic Semren T, Battey JND, Guy PA, Ivanov NV, van der Plas A and Hoeng J (2021) A Literature Review and Framework Proposal for Halitosis Assessment in Cigarette Smokers and Alternative Nicotine-Delivery Products Users.

Front. Oral. Health 2:777442.

doi: 10.3389/froh.2021.777442

\section{A Literature Review and Framework Proposal for Halitosis Assessment in Cigarette Smokers and Alternative Nicotine-Delivery Products Users}

\author{
Filippo Zanetti ${ }^{\star}$, Tanja Zivkovic Semren ${ }^{\dagger}$, James N. D. Battey ${ }^{\dagger}$, Philippe A. Guy, \\ Nikolai V. Ivanov, Angela van der Plas and Julia Hoeng \\ PMI R\&D, Philip Morris Products S.A., Neuchâtel, Switzerland
}

Halitosis is a health condition which counts cigarette smoking (CS) among its major risk factors. Cigarette smoke can cause an imbalance in the oral bacterial community, leading to several oral diseases and conditions, including intraoral halitosis. Although the best approach to decrease smoking-related health risks is quitting smoking, this is not feasible for many smokers. Switching to potentially reduced-risk products, like electronic vapor products (EVP) or heated tobacco products (HTP), may help improve the conditions associated with CS. To date, there have been few systematic studies on the effects of CS on halitosis and none have assessed the effects of EVP and HTP use. Self-assessment studies have shown large limitations owing to the lack of reliability in the participants' judgment. This has compelled the scientific community to develop a strategy for meaningful assessment of these new products in comparison with cigarettes. Here, we compiled a review of the existing literature on CS and halitosis and propose a 3-layer approach that combines the use of the most advanced breath analysis techniques and multi-omics analysis to define the interactions between oral bacterial species and their role in halitosis both in vitro and in vivo. Such an approach will allow us to compare the effects of different nicotine-delivery products on oral bacteria and quantify their impact on halitosis. Defining the impact of alternative nicotine-delivery products on intraoral halitosis and its associated bacteria will help the scientific community advance a step further toward understanding the safety of these products and their potentiall risks for consumers.

Keywords: halitosis, cigarette smoke, reduced risk products, electronic vapor product, heated tobacco product

\section{INTRODUCTION}

Halitosis-also known as fetor ex ore, fetor oris, bad or foul breath, breath malodor, and oral malodor-is a common condition that affects $15-60 \%$ of the population worldwide, with marked regional differences [1-3]. Halitosis is characterized by an unpleasant odor in exhaled breath [4]. The causes of halitosis are numerous and include poor oral hygiene, periodontal diseases, dry mouth, cigarette smoking (CS)/tobacco use, alcohol consumption, dietary habits, diabetes, and obesity. Other causes include aging, stress, the general hygiene of the body, and the use of certain medications [5-9]. 
There are two types of halitosis: extraoral halitosis $(\mathrm{EOH})$ and intraoral halitosis $(\mathrm{IOH})$ [10]. A small percentage of halitosis cases (5-10\%) are of extraoral origin. This type of halitosis can be caused by diabetes, metabolic disorders, kidney and liver diseases, as well as certain drugs and foods [11]. The vast majority of halitosis cases (80-90\%), however, originate from the oral cavity; this form of halitosis is caused in general by poor oral hygiene, dental plaque, dental caries, gingivitis, stomatitis, periodontitis, tongue coating, and in rare cases oral carcinoma [12]. Dry mouth (xerostomia) might also promote oral malodor [13], although a correlation has not always been observed [14]. In healthy subjects, the most common source of oral malodor is the coating of the tongue (43.4\% of cases of $\mathrm{IOH}$ ) [15]. Tongue coating consists of bacteria, large quantities of desquamated epithelial cells, blood metabolites, food debris, and leucocytes originating from periodontal pockets, which accumulate easily because of the anatomical structure of the tongue [16]. The principal site of oral malodor is the dorsoposterior part of the tongue, which is where the most of anaerobic bacteria responsible for malodor grow [14, 16] (Figure 1).

$\mathrm{IOH}$ is the outcome of the production of volatile organic compounds (VOC) mainly by bacterial metabolism in the oral cavity. Almost 700 compounds have been detected in the oral cavity, of which volatile sulfuric compounds (VSC) like hydrogen sulfide and methyl mercaptan are the most abundant (90\%) in IOH owing to their low odor threshold and high volatility [1721]. Dimethyl sulfide is also a very abundant VSC in halitosis, but it is associated with $\mathrm{EOH}$ [22]. These VSCs are the main compounds responsible for oral malodor [23]. Other VOCs that contribute to halitosis are short-chain fatty acids, amines, and indols. VSCs are mainly produced by the metabolism of sulfur amino acids by anaerobic bacteria present in the tongue coating, and the quantity of volatiles produced is associated with the population density of the bacteria on the tongue [24]. VSCs and other VOCs have been shown to be deleterious to oral soft tissues and to induce changes that may lead to carcinogenesis [25-27]. Other compounds responsible for halitosis are diamines, such as trimethylamine, putrescine and cadaverine, produced by the putrefaction of food by bacteria [28].

The impact of cigarettes and alternative nicotine-delivery products on halitosis has not been systematically addressed so far. In this document, we will review the studies conducted on this topic and propose a framework for the systematic assessment and comparison of the effects of cigarette smoke and alternative nicotine-delivery products on $\mathrm{IOH}$ by leveraging state-of-the-art omics technologies for breath and microbiome analysis.

\section{ORAL MICROBIOME AND HALITOSIS}

In humans, the oral cavity contains a high density and diversity of bacteria, second only to the colon [29]. It is estimated that the bacteria populating the oral cavity belong to around 700 taxa [30]. The composition of tongue microbiota is of primary importance in the development of $\mathrm{IOH}$ [31]. The tongue structure presents papillae, deep fissures, and crypts, which represent a niche with low oxygen potential, ideal for the growth of anaerobic bacteria associated with halitosis [32]. The tongue bacterial diversity in halitosis patients seems to be higher than that of controls [5]; it has been observed that the bacterial diversity in halitosis patients ( $n=16$; analyzed by $16 \mathrm{~S}$ rRNA gene pyrosequencing and metagenomics methods) encompasses a wide range of microbial communities, including 13 phyla, 23 classes, 37 orders, 134 genera, 266 species, and 349 operational taxonomic units [33]. IOH is associated with the increased activity or abundance of certain bacterial genera, such as Fusobacterium, Porphyromonas, Prevotella, and Tannerella, in tongue biofilms $[34,35]$. A specific biofilm on the dorsal part of the tongue seems responsible for halitosis: A study that combined fluorescence in situ hybridization and confocal laser microscopy analyses identified that Fusobacterium nucleatum and Streptococcus spp. cover a significant proportion of the bacterial biofilm in halitosis patients [36]. Another study applied an untargeted approach and identified that Actinomyces graevenitzii and Veillonella rogosae are closely related to the occurrence of IOH; according to this study, Streptococcus mitis/oralis, Streptococcus pseudopneumoniae, and Salmonella infantis, as well as Prevotella spp. are often detected in the tongue coating of halitosis patients [37]. The density of bacterial population on the tongue but not the thickness of the biofilm seems to correlate with the production of VSCs [38-40].

The prevalence of gram-negative bacteria is associated with halitosis [41]. Among gram-negative bacteria, Prevotella, Alloprevotella, Leptotrichia, and Peptostreptococcus are present at a higher percentage in subjects with halitosis than in healthy subjects [33]. Gram-negative anaerobes are the most active producers of hydrogen sulfide; among these bacteria, Porphyromonas gingivalis, Treponema denticola, and Tannerella forsythia, which belong to the red complex, are associated with periodontal diseases and positively correlated with $\mathrm{IOH}[5,22$, 42]. For example, it has been shown that hydrogen sulfide and methyl mercaptan are abundantly produced at sites of periodontal inflammation [43-45]. Moreover, Porphyromonas spp., Prevotella spp., and Treponema denticola may play a crucial role in providing amino acids to other anaerobic bacteria to produce hydrogen sulfide and methyl mercaptan [46]. Porphyromonas gingivalis, Prevotella intermedia, and Fusobacterium nucleatum are the major producers of indole and skatole (also called 3-methylindole) [47]. Gram-positive bacteria have also a function in $\mathrm{IOH}$ : They can support gramnegative anaerobic bacteria by removing sugar chains from glycoproteins and providing necessary proteins during the proteolytic processes [46].

CS has a major impact on the composition of the oral microbiome. In the next section, we will discuss the current knowledge on the connection between CS, microbiome, and $\mathrm{IOH}$.

\section{CS, ORAL BACTERIA, AND HALITOSIS}

CS is considered to be one of the major risk factors for the development of several health conditions and diseases, including many oral diseases. CS can contribute to halitosis 


\section{Genuine halitosis}

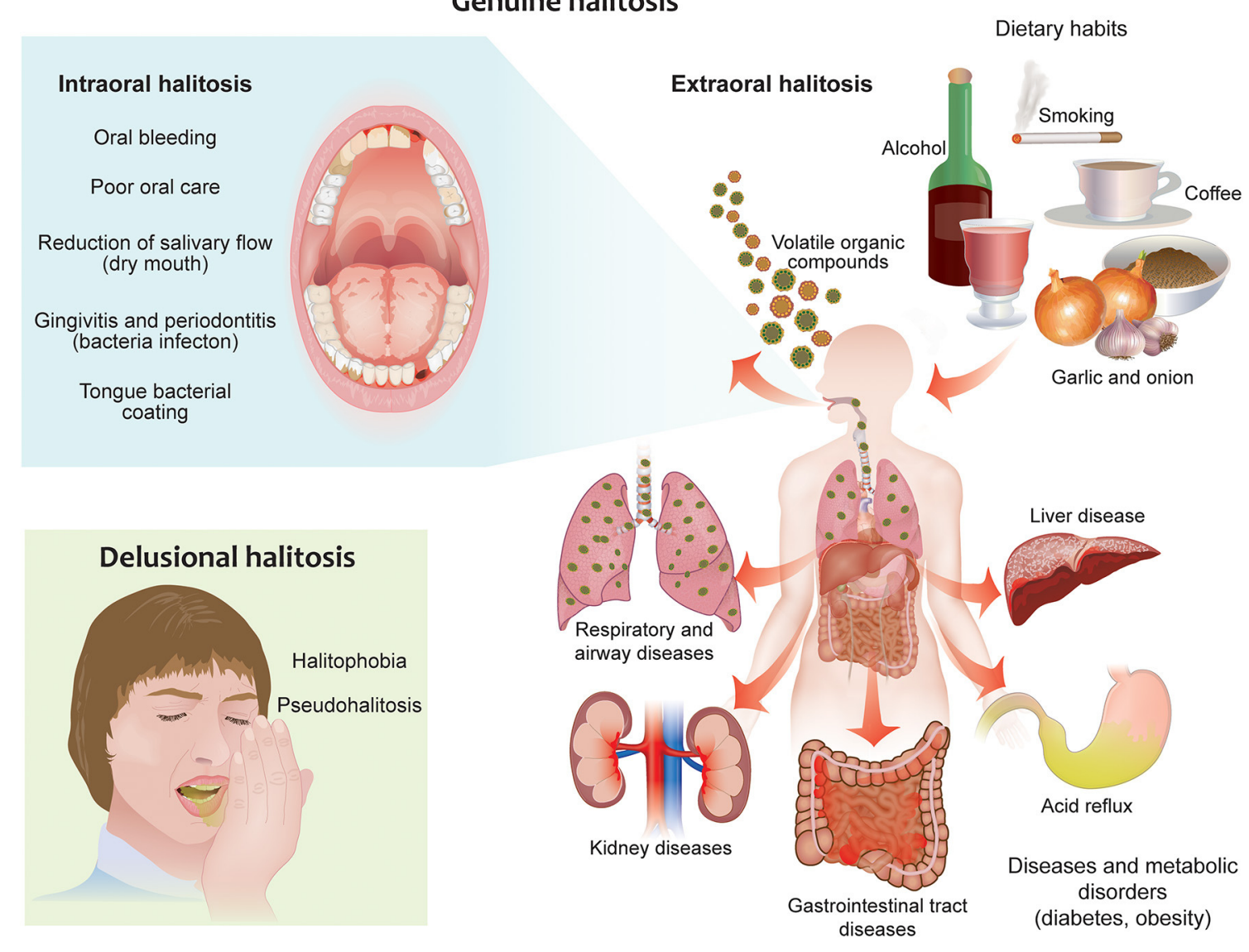

FIGURE 1 | Different forms of halitosis and their causes. Genuine halitosis can be classified as intraoral or extraoral halitosis. Intraoral halitosis originates from volatile organic compounds produced by oral bacteria resulting from poor oral hygiene, dental plaque, dental caries, oral diseases, tongue coating, and dry mouth. In extraoral halitosis, the malodor is emitted from the nasal, paranasal, laryngeal, or pulmonary regions and can be caused by serious diseases like diabetes, metabolic disorders, and kidney and liver diseases. Certain foods, beverages, and lifestyle habits, like cigarette smoking and alcohol consumption, can also contribute to halitosis. Delusional halitosis occurs when no physical or social evidence exists for the presence of halitosis (pseudohalitosis); delusional halitosis may also be related to a psychogenic or psychosomatic disorder (halitophobia).

by causing hyposalivation, thereby facilitating the formation of deposits on the tongue [48]. CS can also contribute to the onset of periodontal diseases, which are strictly correlated with alterations in the oral microbiome composition [49, 50]. Cigarette smoke contains many toxicants that can alter the oral microbiome through different mechanisms such as antibiotic effects and oxygen deprivation [51]. Lower salivary $\mathrm{pH}$ has been observed in smokers compared to healthy controls leading to microbial unbalance and erosion of the enamel [52]. CS can decrease the commensal population in the oral cavity, facilitating the acquisition and colonization of periodontal pathogens (Figure 2). Smokers exhibit a distinct subgingival microbial composition than non-smokers [53], although previous studies have reported conflicting results [reviewed in [50]], likely because of differences in the sensitivity and specificity of the methods used. CS has been shown to promote the cariogenic activity of oral bacteria [54]. The tongue bacterial composition of current smokers has been found to be different from that of nonsmokers: A recent study by Sato et al. [55] identified the anaerobe
Veillonella dispar as the most differentially abundant bacterial species in the tongue coating of smokers vs. non-smokers. This specific Veillonella species was reported to produce hydrogen sulfide as a product of L-cysteine metabolism [56]. Interestingly, Candida species have also been found to be some of the most abundant species in smokers with halitosis [57]. Al-Zyoud and colleagues identified a bacterial signature in the saliva of smokers that included Prevotella, Streptococcus, and Veillonella, which are bacterial genera that include strains associated with oral malodor; however, the authors did not perform any investigation at the species level or analyze for correlation with halitosis [58]. In another study that analyzes the bacterial composition of the saliva and tongue coating of smokers and non-smokers, the levels of Fusobacterium nucleatum and Campylobacter rectus in smokers were 5-fold greater than those in non-smokers and showed positive correlation with VSC levels [59].

Halitosis is still one of the major concerns in smokers: In a recent survey, $73 \%$ of smokers reported that they are afraid of developing such a condition [60]. Cigarette smokers are 
Effects of smoke on intraoral health

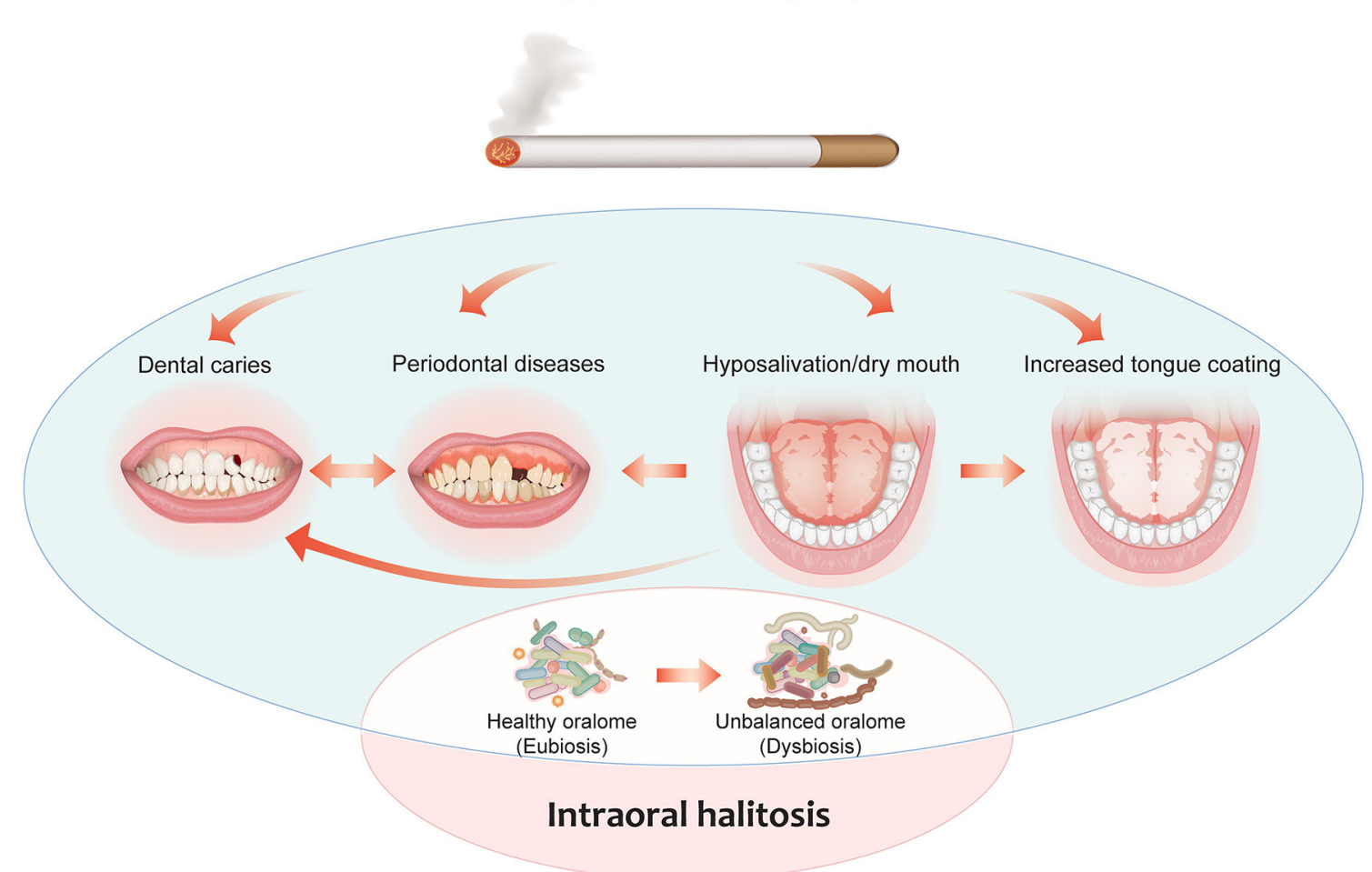

FIGURE 2 | Effects of cigarette smoking on intraoral halitosis. Cigarette smoke can contribute to halitosis by causing hyposalivation, thereby facilitating the formation of deposits on the tongue. It can also contribute to the onset of periodontal diseases and the formation of dental caries. All these effects can decrease the commensal population in the oral cavity, facilitating the acquisition and colonization of periodontal pathogens. This leads to oral dysbiosis, which can, in turn, lead to intraoral halitosis.

indeed reported to have a higher measured and self-perceived incidence of halitosis than non-smokers [61]. In the literature, cigarette smoke-related halitosis is also defined "smoker's breath" [14]. CS contains various components, such as acetaldehyde, benzene, and ammonia, that can confound the measurement of halitosis by organoleptic tests $[62,63]$. Moreover, some problems with interobserver and intraobserver reproducibility have been described [64]. A recent study showed that smokers have a greater probability of less objectively reporting their gingival conditions and halitosis than nonsmokers [6-8]. Unfortunately, most studies that have assessed halitosis in smokers have been conducted through self-assessment surveys (Table 1). Of the five studies that combined self-reported halitosis diagnosis and halitosis measurement by organoleptic judges or by Halimeter results, four did not find a positive correlation between the selfreported halitosis and instrument/organoleptic results [70, 72, 81, 82], while the remaining one study did [85]. This difference in self-reported halitosis and instrument/organoleptic results may be due to the decreased olfactory sensitivity of smokers, which biases their self-perception of breath [1]. Therefore, the use of instruments for measuring oral malodor combined with organoleptic judgement may provide a more accurate diagnosis. To date, only few studies have systematically addressed the correlation of CS with halitosis. One study in subjects with periodontitis found that VSC levels were higher in the gingival pockets of smokers than in non-smokers [86]. In other studies, VSCs and organoleptic scores were significantly associated with bacterial tongue coating and CS [81, 82]. Another study showed that smoking was associated with self-reported halitosis but not with VSC levels [72]. It is noteworthy that some studies have found that smokers have poorer oral hygiene than non-smokers, and this also could play a role in the development of $\mathrm{IOH}[71,87]$.

Quitting smoking has been shown to shift the composition of the oral bacterial population in healthy subjects to a composition similar to that in never smokers, indicating that the cigarette smoke-induced changes in the microbiome are reversible [88]. However, no information has been published on the correlation of quitting CS with halitosis improvement. Interestingly, reduced risk of halitosis is among the suggested reasons for quitting smoking by dentist guidelines in the United Kingdom [89].

\section{IMPACT OF ALTERNATIVE NICOTINE-DELIVERY PRODUCTS ON HALITOSIS}

While cessation is the best practice for reducing the negative effects of CS, only a small percentage of smokers who attempt to quit do not relapse 6 months after [90]. The tobacco harm reduction strategy has recently emerged as a complementary 
TABLE 1 | Studies that have investigated the impact of cigarette smoking on halitosis.

\begin{tabular}{|c|c|c|c|c|}
\hline Reference & Total study participants & Smoking status & $\begin{array}{l}\text { Diagnosis of } \\
\text { halitosis }\end{array}$ & Conclusions \\
\hline Al Ansari et al. [65] & $\begin{array}{l}1,551 \text { (dentistry patients } \\
\text { and random subjects) }\end{array}$ & $\begin{array}{l}\text { Current smokers/former } \\
\text { smokers }\end{array}$ & Self-reported & $\begin{array}{l}\text { Halitosis perception significantly higher in smokers and former } \\
\text { smokers than in non-smokers }\end{array}$ \\
\hline Alqahtani et al. [66] & $\begin{array}{l}100 \text { (peri-implantitis } \\
\text { patients) }\end{array}$ & $\begin{array}{l}\text { Current } \\
\text { smokers/waterpipe users }\end{array}$ & Self-reported & $\begin{array}{l}\text { Significantly more smokers and waterpipe users reported } \\
\text { halitosis than non-smokers }\end{array}$ \\
\hline AISadhan [3] & $\begin{array}{l}2,343 \text { (random subjects } \\
\text { from a school and } \\
\text { government office) }\end{array}$ & $\begin{array}{l}\text { Current } \\
\text { smokers/waterpipe users }\end{array}$ & Self-reported & $\begin{array}{l}\text { Smoking and waterpipe use was significantly associated with } \\
\text { halitosis }\end{array}$ \\
\hline $\begin{array}{l}\text { Al-Zahrani et al. } \\
{[67]}\end{array}$ & 38 (diabetes patients) & $\begin{array}{l}\text { Current smokers/former } \\
\text { smokers }\end{array}$ & Self-reported & $\begin{array}{l}\text { No significant association between smoking and halitosis, } \\
\text { although the study contained only one current smoker }\end{array}$ \\
\hline $\begin{array}{l}\text { Ayo-Yusuf et al. } \\
\text { [68] }\end{array}$ & 896 (dentistry patients) & Current smokers & $\begin{array}{l}\text { Organoleptic } \\
\text { measurement }\end{array}$ & $\begin{array}{l}\text { Smoking significantly associated with high organoleptic } \\
\text { ratings }\end{array}$ \\
\hline $\begin{array}{l}\text { Babazadeh et al. } \\
\text { [69] }\end{array}$ & 519 (adolescents) & $\begin{array}{l}\text { Current } \\
\text { smokers/waterpipe users }\end{array}$ & Self-reported & Halitosis associated with poor oral health in smokers \\
\hline Eldarrat et al. [70] & $\begin{array}{l}233 \text { (undergraduate and } \\
\text { graduate students) }\end{array}$ & Current smokers & Self-reported & $\begin{array}{l}\text { Smoking was not correlated with halitosis, although a greater } \\
\text { number of smokers reported halitosis than non-smokers }\end{array}$ \\
\hline Jiun et al. [71] & 200 (dentistry patients) & Current smokers & Halimeter & $\begin{array}{l}75 \% \text { of smoking subjects show halitosis vs. } 8 \% \text { of } \\
\text { non-smokers; the difference was statistically significant }\end{array}$ \\
\hline Lee et al. [72] & $\begin{array}{l}54 \text { (visitors at a health } \\
\text { center) }\end{array}$ & $\begin{array}{l}\text { Current smokers/former } \\
\text { smokers }\end{array}$ & $\begin{array}{l}\text { Self-reported, } \\
\text { Halimeter }\end{array}$ & $\begin{array}{l}\text { Smoking significantly associated with self-conscious and } \\
\text { self-reported halitosis but not associated with halitosis } \\
\text { diagnosed by a Halimeter }\end{array}$ \\
\hline Rech et al. [73] & $\begin{array}{l}48 \text { (pneumology clinic } \\
\text { patients and random } \\
\text { subjects) }\end{array}$ & Current smokers & Self-reported & $\begin{array}{l}33 \% \text { of smokers reported halitosis vs. } 4.2 \% \text { of non-smokers. } \\
\text { Halitosis more common in subjects who had smoked for } \\
\text { more than } 20 \text { years }\end{array}$ \\
\hline Romano et al. [74] & 736 (Dentistry patients) & Current smokers & $\begin{array}{l}\text { Self-reported, } \\
\text { organoleptic } \\
\text { measurement }\end{array}$ & $\begin{array}{l}\text { Heavy smoking negatively associated with the concordance } \\
\text { of self-reporting and organoleptic measurement of halitosis }\end{array}$ \\
\hline $\begin{array}{l}\text { Saadaldina et al. } \\
\text { [75] }\end{array}$ & 460 (Dentistry patients) & Current smokers & Self-reported & Smoking significantly associated with halitosis \\
\hline Şanli et al. [76] & $\begin{array}{l}1,840 \text { (ear, nose, and } \\
\text { throat clinic patients) }\end{array}$ & $\begin{array}{l}\text { Current smokers/former } \\
\text { smokers }\end{array}$ & Self-reported & $\begin{array}{l}37.7 \% \text { of smokers reported halitosis vs. } 22.4 \% \text { of } \\
\text { non-smokers }\end{array}$ \\
\hline Struch et al. [77] & $\begin{array}{l}\text { 3,005 (random subjects } \\
\text { [citizens]) }\end{array}$ & $\begin{array}{l}\text { Current smokers/former } \\
\text { smokers }\end{array}$ & Self-reported & $\begin{array}{l}\text { Former smokers and smokers reported halitosis more often } \\
\text { than never smokers }\end{array}$ \\
\hline Setia et al. [78] & 277 (dental students) & Current smokers & Self-reported & Halitosis reported by $80 \%$ of smokers \\
\hline Silva et al. [45] & $\begin{array}{l}900 \text { (random subjects } \\
\text { [citizens]) }\end{array}$ & Current smokers & Self-reported & $\begin{array}{l}\text { Interaction of the effects of smoking and periodontitis on } \\
\text { halitosis }\end{array}$ \\
\hline $\begin{array}{l}\text { Tubaishat et al. } \\
\text { [79] }\end{array}$ & $\begin{array}{l}580 \text { (random subjects from } \\
\text { a school) }\end{array}$ & Current smokers & Self-reported & $58.5 \%$ of smokers reported halitosis \\
\hline Barik et al. [80] & $\begin{array}{l}\text { 16,354 (random subjects } \\
\text { [citizens]) }\end{array}$ & $\begin{array}{l}\text { Current } \\
\text { smokers/smokeless } \\
\text { tobacco users }\end{array}$ & Self-reported & $\begin{array}{l}0.2 \% \text { of smokers and } 0.1 \% \text { of smokeless tobacco users } \\
\text { reported halitosis }\end{array}$ \\
\hline $\begin{array}{l}\text { Bornstein et al. } \\
\text { [81] }\end{array}$ & $\begin{array}{l}419 \text { (random subjects } \\
\text { [citizens]) }\end{array}$ & Current smokers & $\begin{array}{l}\text { Self-reported, } \\
\text { organoleptic } \\
\text { measurement, } \\
\text { Halimeter }\end{array}$ & $\begin{array}{l}\text { Positive correlation of smoking, tongue coating, and } \\
\text { periodontal screening index with halitosis; weak correlation } \\
\text { between self-reported halitosis and VSC measurements and } \\
\text { organoleptic scores }\end{array}$ \\
\hline $\begin{array}{l}\text { Bornstein et al. } \\
\text { [82] }\end{array}$ & 626 (army recruits) & Current smokers & $\begin{array}{l}\text { Self-reported, } \\
\text { organoleptic } \\
\text { measurement, } \\
\text { Halimeter }\end{array}$ & $\begin{array}{l}\text { Positive correlation of smoking and tongue coating with } \\
\text { halitosis; inverse correlation between smoking and VSC } \\
\text { levels; no correlation between self-reported halitosis and } \\
\text { organoleptic scores or VSC measurements }\end{array}$ \\
\hline $\begin{array}{l}\text { Kayombo et al. } \\
\text { [83] }\end{array}$ & 400 (workers) & Current smokers & Self-reported & $\begin{array}{l}25.8 \% \text { of smokers reported halitosis; the association was } \\
\text { statistically significant }\end{array}$ \\
\hline Kim et al. [84] & 359,263 (adolescents) & Current smokers & Self-reported & $\begin{array}{l}\text { Smoking not statistically correlated with halitosis; smokers' } \\
\text { cohort was small }\end{array}$ \\
\hline Miyazaki et al. [85] & 2,672 (workers) & Current smokers & $\begin{array}{l}\text { Self-reported, } \\
\text { Halimeter }\end{array}$ & $\begin{array}{l}\text { Smoking, tongue coating, and self-diagnosis significantly } \\
\text { associated with VSC production }\end{array}$ \\
\hline Khaira et al. [86] & 33 (periodontitis patients) & Current smokers & $\begin{array}{l}\text { Perio2000 } \\
\text { system }\end{array}$ & $\begin{array}{l}\text { Higher percentage of sites with VSCs in smokers than in } \\
\text { non-smokers }\end{array}$ \\
\hline
\end{tabular}

Data accessed in June 2021. 
approach for helping reduce the adverse effects of CS [91]. The concept of tobacco harm reduction is to switch smokers to less harmful products that emit significantly lower levels of toxicants while still delivering nicotine at comparable levels to cigarettes $[92,93]$. Currently, two classes of products that have the potential to fulfill these characteristics are being marketed: electronic vapor products (EVP) and heated tobacco products (HTP). It is important to conduct robust scientific studies to determine the reduced risk potential of these products in comparison with cigarette smoke.

So far, very few studies have investigated halitosis in relation to such alternative products and CS. EVPs and HTPs are generally perceived to have no impact on breath or less impact than cigarette smoke. A recent automated data mining study investigated more than 41,000 online forum posts related to the effects of EVPs [94] and identified only 5 posts in relation to halitosis and EVPs. Another survey investigated HTPs and EVPs and found that only 9 and $6 \%$ of users, respectively, reported halitosis vs. $86 \%$ of cigarette smokers [61]. In a study by Soule et al., a cluster of 12 patients out of 49 EVP users reported a bad taste in the mouth, deadened taste buds/sense of taste, bad breath, or a metallic taste in the mouth [95]; the authors did not report the actual frequency of bad breath (halitosis).

However, as previously mentioned, self-reported halitosis often does not correspond to objective (measured) halitosis $[81,82,96]$. A recent microbiome study suggested that the salivary bacterial composition of EVP users with periodontitis varies from that of never smokers and smokers and shows more similarities with the composition in non-smokers than smokers [97]. Another recent study investigated the microbiome profile in saliva and buccal samples of EVP users compared with nonsmokers/non-vapers, finding significant changes in the diversity composition in the saliva between the 2 groups [98]. However, these studies did not investigate the possible correlation between a shift in the bacterial composition and halitosis. The use of electronic nicotine-delivery products is speculated to lead to bad breath due to the dry mouth (xerostomia) attributed to the nicotine-related inhibition of salivary flow [99]. Xerostomia can also lead to an imbalance in the oral bacterial population, tipping it toward a greater prevalence of anaerobic species, which are often related with halitosis [8]. However, no study has performed a systematic measurement of halitosis-related compounds in EVP or HTP users so far.

\section{ASSESSMENT OF HALITOSIS}

Halitosis is a source of embarrassment and social challenge, and it significantly influences the social life of affected subjects [100]. A study conducted in the Netherlands showed that halitosis was among the 100 most common causes of distress in the human population [101]. Many people who experience halitosis seek medical advice, and halitosis can be the third most common reason for dentistry visits, behind dental caries and periodontitis [102]. The social pressure of having a fresh breath pushes many people to be preoccupied about this condition. However, self-perceived oral malodor does not always reflect a clinical condition, and it is, therefore, important to discriminate between "genuine halitosis," when the malodor is easily recognizable, and "delusional halitosis," which may instead relate to a psychogenic or psychosomatic disorder (halitophobia) [103]. Delusional halitosis may indicate depression or obsessive-compulsive behavior, necessitating psychiatric care [101]. Anxiety itself increases the oral levels of malodor-associated compounds; consequently, many professionals do not consider self-reporting of halitosis reliable [104]. Assessment methods are, therefore, important for discriminating genuine halitosis from delusional halitosis and for determining the severity of the condition.

In the context of tobacco research, systematic measurement of the volatile compounds present in the breath of EVP and HTP users will help understand the potentially reduced impact of these products on breath odor in comparison with cigarette smoke.

For an exhaled breath analysis, some general rules regarding beverage consumption and personal hygiene should be followed to minimize any interference that may cause results to be interpreted incorrectly. The general instructions for participants are to avoid using a mouthwash for at least $30 \mathrm{~min}$ prior to the exhalation measurement, refrain from eating, smoking, drinking (besides water), or any oral hygiene activity for $1-2 \mathrm{~h}$ prior to the test [105]. In addition, participants should avoid consuming garlic, onions, or spicy food for 2 days before their appointment (as these foods are a source of sulfur compounds) and also refrain from drinking alcohol or coffee for $12 \mathrm{~h}$ before the measurement [21]. The potential of certain foods and beverages to mask odor need to be considered. Hansanugrum and Barringer reported the benefits of drinking whole milk as a way to reduce the presence of diallyl disulfide and allyl methyl disulfide after garlic consumption [106]. Similarly, the levels of methanethiols and allylthiols are significantly reduced when garlic is rinsed with a mushroom (Agaricus bisporus) extract before ingestion [107]. Enzymatic deodorization involving oxidation of polyphenolic compounds by enzymes (e.g., alliinase) as well as the presence of polyphenols without enzyme activity or acidic deodorization have been proposed as tools for reducing oral malodor [108, 109].

Diagnostic methods rely primarily on organoleptic (intensity) or hedonic (pleasant/unpleasant) assessment of breath by trained panel. This approach is considered the standard for halitosis diagnosis [110]. However, it can be difficult to compare results across different trained sensory panelists, as the methodology may vary in terms of both the definition of odor attributes as well as the intensity ranking scale. Analytical technique gas chromatography (GC) coupled to mass spectromety (MS), considered as the gold standard for VOC analysis, has been applied to identify chemical markers associated with malodor. The findings of studies employing these methods have led to the development of different sensor (portable) instruments for halitosis diagnosis (Table 2) [111]. As an example, total sulfuric compound measurements can be monitored by using a portable Halimeter (Interscan Corporation, Chatsworth, CA, USA), which is based on a volumetric non-selective gas sensor. This instrument has been shown to provide good reproducibility. However, the main drawback of the Halimeter is that it cannot discriminate different VSCs [110]. By contrast, OralChroma (Abimedical, 
TABLE 2 | Comparison of direct exhaled breath measurement methods applicable in halitosis research.

\begin{tabular}{|c|c|c|c|c|}
\hline $\begin{array}{l}\text { Direct measurement methods } \\
\text { applicable in halitosis } \\
\text { research }\end{array}$ & $\begin{array}{l}\text { Implemented in } \\
\text { halitosis research }\end{array}$ & Sensitivity level of detection & Quantification & $\begin{array}{l}\text { Untargeted analysis } \\
\text { (biomarker research) }\end{array}$ \\
\hline Organoleptic & YES & $\begin{array}{l}\text { Only approach that can predict } \\
\text { the degree of odor that a gas } \\
\text { mixture may impart to the human } \\
\text { nose }\end{array}$ & $\begin{array}{l}\mathrm{NO} \\
\text { Exhaled breath smell is ranked from } 0 \\
\text { (undetectable) to } 5 \text { (heavy foul odor) }\end{array}$ & NO \\
\hline \multicolumn{5}{|l|}{ Sensors } \\
\hline Halimeter (Interscan Corporation) & YES & $\mathrm{ppb}$ & $\begin{array}{l}\text { YES } \\
\text { - Provides quantification of total } \\
\text { sulfuric compounds, } \\
\text { - Cannot differentiate between } \\
\text { sulfuric compounds, } \\
\text { - Insensitive to non-sulfuric } \\
\text { volatile compounds }\end{array}$ & NO \\
\hline Oralchroma (Abimedical) & YES & ppb & $\begin{array}{l}\text { YES } \\
\text { - Quantification of } \mathrm{H}_{2} \mathrm{~S}, \mathrm{CH}_{3} \mathrm{SH} \text {, } \\
\left(\mathrm{CH}_{3}\right)_{2} \mathrm{~S} \text {, } \\
\text { - Insensitive to non-sulfuric } \\
\text { volatile compounds }\end{array}$ & NO \\
\hline NeOse (Aryballe) & YES & $\begin{array}{l}\text { Compound-dependent } \\
\text { Ammonia (LOD } 20 \text { ppb) } \\
\text { Hydrogen sulfide (LOD } 50 \text { ppb) }\end{array}$ & $\begin{array}{l}\text { NO } \\
\text { - "Digital olfaction", } \\
\text { - Can identify different odors on the } \\
\text { basis of records within an } \\
\text { Al database }\end{array}$ & $\mathrm{NO}$ \\
\hline \multicolumn{5}{|l|}{ Real-time Ms techniques } \\
\hline SIFT-MS & YES & $\begin{array}{l}\text { ppt } \\
\text { (Compound-dependent) }\end{array}$ & YES & $\begin{array}{l}\text { NO } \\
\text { (More targeted approach) }\end{array}$ \\
\hline PTR-MS & NO & $\begin{array}{l}\text { ppt } \\
\text { (Compound-dependent) }\end{array}$ & YES & $\begin{array}{l}\text { YES } \\
\text { (Low capability for } \\
\text { compound identification) }\end{array}$ \\
\hline Super SESI-HR-MS & NO & $\begin{array}{l}\text { ppt } \\
\text { (Compound-dependent) }\end{array}$ & NO & $\begin{array}{l}\text { YES } \\
\text { (Enhanced capabilities for } \\
\text { compound identification) }\end{array}$ \\
\hline
\end{tabular}

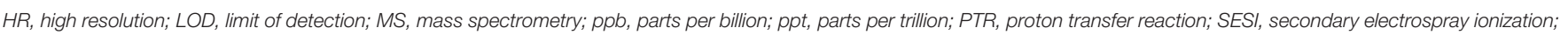
SIFT, selected ion flow tube.

Abilit Corp., Osaka, Japan) can differentiate between hydrogen sulfide, methyl mercaptan, and dimethyl sulfide by means of rapid GC separation [110].

Recent developments in the analysis of odors and fragrances include the introduction of the portable NeOse device (Aryballe Technologies, Grenoble, France), which is based on the silicon photonics technology [112]. Through a combination of artificial intelligence data processing, this biosensor is able to monitor VOCs and has the potential to reveal the distinct signature of halitosis [113]. A recent comparison of current measurement instruments showed that the data generated from the NeOse biosensor correlate well with both selected-ion flow-tube (SIFT) coupled to MS measurements and organoleptic scoring. This is a promising insight for the future development of point-of-care halitosis measurement methods [113].

However, these portable instruments do not provide a holistic analysis of compounds (untargeted analysis) and do not allow the discovery of novel chemical markers in exhaled breath.

Several indirect measurement techniques exist which address the presence of bacteria associated with $\mathrm{IOH}$ rather than the target compounds [reviewed in [114]].

\section{A Multiomics Approach for Holistic Understanding of Halitosis Related to the Oral Microbiome}

A holistic approach can help highlight the interrelationships among oral bacterial species, their metabolism, and the volatile compounds that are ultimately responsible for halitosis. The advent of high-throughput omics technologies has allowed the detection of a wider range of bacterial taxa associated with $\mathrm{IOH}$ as well as the characterization of their metabolites. Combining multiple omics technologies has an advantage over using a single omics approach in that it provides a greater understanding of the disease, from its original cause (genetic, developmental, or environmental) to its functional consequences or relevant interactions $[115,116]$. Integration of different omics approaches may help us gather comprehensive information on the function of the oral microbiome in halitosis [117]. The different omics data that are found to correlate with halitosis, such as microbiomics and metabolomics data, can be fit into a logical framework to discover the responsible molecular pathways that elucidate the role of the different bacteria responsible for halitosis [118, 119]. 
A multiomics approach may also be of great help in linking environmental factors, such as CS or the use of alternative nicotine-delivery products, to changes in the microbiome and metabolome.

\section{Microbiomics}

In the past, microbiome investigations have often focused on culturing techniques, which are laborious and limited to taxa that are amenable to in vitro culturing. In recent times, there has been a shift toward high-throughput techniques for obtaining snapshots of the composition of the microbiome. One of the main classes of molecules used for this purpose are the nucleic acids. In principle, detecting sequences distinct to a specific taxon allows us to infer the presence and even abundance of that taxon.

PCR-based methods can help identify target species in samples and have been used for investigating the link between the microbiome and halitosis [120, 121]. In fact, primer panels have been devised for oral microbiome investigations [122]. The method is generally limited to microorganisms for which sequence information is available, and it only allows a limited set of predefined organisms to be surveyed. Terminal restriction fragment length polymorphism analysis of $16 \mathrm{~S}$ sequences has been used for species identification [40], especially in conjunction with machine learning [123], but the method has not gained popularity. The most used method currently is 16S rRNA gene sequencing, which involves amplifying and sequencing one or more of the hypervariable regions in the $16 \mathrm{~S}$ ribosomal subunit gene and assigning a taxonomic classification on the basis of homology to known sequences. This method has been used abundantly in halitosis research [31, 33, 124] and notably in direct connection with the effect of CS on halitosis [58]. Amplicon sequencing offers an affordable undirected approach for investigating the microbiome which is not limited to specific bacteria. It is, however, limited to taxonomic profiling and cannot directly provide information on metabolic activity.

More recently, shotgun sequencing has been used for microbiome analysis. This method yields a snapshot of all the DNA in a sample. Sequencing reads can then be either assigned a provenance by homology to known microbial sequences, or assembled into "metagenome" fragments and then used for functional analysis, thus potentially obtaining information on both taxonomy and metabolism. While it is more resourceintensive than simple amplicon sequencing, shotgun sequencing might be preferable because of its broader scope of use. Largescale metagenomics projects have already characterized several niches of the human microbiome, including the oral microbiome [125]. Other shotgun approaches have investigated the tongue microbiome of smokers vs. non-smokers [55].

\section{Metabolomics}

Metabolomics is a fast-emerging discipline in systems biology and represents the study of all low-molecular-weight molecules present in a biological sample. The metabolome is the sum of all molecules in a biological organism or system and usually contains vast information about the end products of cellular processes [126]. Volatilomics, breathomics, and salivaomics are three branches of metabolomics that can be applied as the most modern approaches for studying halitosis.

Volatilomics is focused on the analysis of the VOCs emitted by a living organism and is integrated with breathomics and salivaomics research $[127,128]$. VOCs can be detected in the headspace area of saliva [129] and directly in exhaled breath [130]. It is mostly GC-MS detection that is used for studying the VOCs present in saliva. This technique has already been applied in halitosis research, where a study recently identified two potential biomarkers of halitosis: 5 -aminovaleric acid and $\mathrm{N}$-acetylornithine [131]. Monedeiro et al. have reported 164 VOCs in saliva, which they monitored by headspace solid-phase microextraction coupled to GC-MS (HS-SPME-GC-MS). Of the 164 VOCs, 23 are specific to halitosis (including a large number of sulfuric compounds) and 41 to abscesses (a greater variety of alcohols, aldehydes, and hydrocarbons, which are biomarkers of inflammatory processes) [132]. Another study has reported significantly higher concentrations of salivary cortisol in subjects with psychosomatic halitosis than in subjects with genuine halitosis and control subjects $(p<0.05)$ [133]. Additionally, salivary cysteine-a direct precursor of hydrogen sulfide-can be considered a reliable marker for assessing the severity of oral tissue damage in periodontitis patients [134].

Breathomics is a branch of metabolomics that explores the compounds present in human breath by using various analytical techniques [135-137]. This approach helps clarify the link between breath molecules and certain diseases/conditions $[135,138]$. The list of diseases/conditions that are related to breath molecules is not limited to halitosis but also includes metabolic, lung, and gastrointestinal disorders [139]. The recently introduced human breathomics database (HBDB; https://hbdb.cmdm.tw/) provides scientists a tool for identifying and further investigating potential breath biomarkers [136]. The database is currently updated with 913 compounds that are related to 60 diseases (accessed in August 2021).

Exhaled breath analysis can involve two approaches: off-line and on-line (real-time) measurement. The off-line approach involves collection of exhaled breath, sample analysis, and data analysis [140]. Exhaled breath collection includes collection of the gas phase of exhaled breath by using sampling bags or bottles (for example) and collection of exhaled breath condensate by using a condenser. GC-MS and/or liquid chromatography coupled to MS (LC-MS) are usually used for analysis of such samples [127]. The GC-MS off-line analysis is usually performed by thermal desorption of a Tenax tube in which VOCs from the collected samples are trapped. This technique has been used by van den Velde et al. for studying VOCs associated with halitosis in non-halitosis subjects. During sample collection, the authors made a distinction between alveolar and mouth air. They instructed the subjects not to breathe for $30 \mathrm{~s}$, so that they could collect mouth air by using a manual piston and Teflon bulb. They then used a commercially available Bio-VOC sampler to collect exhaled alveolar air. The authors detected 14 compounds associated with bad breath and highlighted the importance of differentiating between alveolar and mouth air because of their different chemical compositions [141]. 
Over the last three decades, real-time exhaled breath analysis has been used as a complementary technique to the off-line approach [142-147]. The main difference between the off-line and real-time analyses is that the latter provides (i) results quickly and (ii) does not include exhaled breath sample collection and storage, which can cause loss and degradation of compounds. Bruderer et al. have recently reviewed the various methods that allow real-time analysis of exhaled breath [148], including the three main approaches: proton transfer reaction (PTRMS], selected-ion flow-tube (SIFT-MS), and the more recent secondary electrospray ionization (Super SESI) MS (Table 2). These approaches allow measurement of oral malodor directly in the oral cavity and can also be adapted for measurement of bacteria cultivated in vitro [149].

SIFT-MS has already been employed as a real-time analytical method for monitoring and quantifying hydrogen sulfide, methanethiol, and dimethyl sulfide in research related to mitigating the effects of a dentifrice on halitosis [23]. SIFTMS has proven to be the technique of choice for detecting and quantifying VSCs in exhaled air with high sensitivity up to the low ppb levels. It is perfectly suited for targeted analysis and can provide accurate concentration measurements. However, the main drawback of this technique is that it currently cannot be applied in untargeted analysis (which would allow discovery of new biomarkers), as the mass analyzer does not offer high-resolution accurate mass analysis capabilities [148] (Table 2).

To our knowledge, neither PTR-MS nor Super SESI-MS has yet been used in halitosis research. PTR-MS can be successfully applied for targeted analysis of the VOCs present in exhaled air, and it can provide quantification up to ppt levels [150]. The exhaled breath VOC levels measured by PTR-MS can be affected by variations in humidity and $\mathrm{CO}_{2}$ and $\mathrm{O}_{2}$ levels [139]. The main drawback of this technique is its low-resolution mass accuracy capability (most PTR time-of-flight mass analyzers have a resolving power $[\mathrm{m} / \Delta \mathrm{m}]$ of $>6,000)$ [151]. Similar to SIFT-MS, PTR-MS is not suited for untargeted identification of chemical markers (Table 2).

Super SESI-HR-MS is the latest among these real-time techniques. It has the main advantages of being able to operate at ambient pressure and couple with any ambient inlet MS, including high-resolution accurate mass capability when coupled to an Orbitrap mass analyzer ( $\mathrm{m} / \Delta \mathrm{m}$ up to 240,000 with a Q Exactive HF series). Moreover, this instrument can generate high-resolution accurate mass MS/MS spectra, which are particularly useful for distinguishing between compounds that have similar elemental formulas [148], hence allowing detection and identification of new biomarkers related to halitosis. The current main drawback of Super SESI-HR-MS compared with SIFT-MS and PTR-MS is that it does not provide absolute quantification [148] (Table 2). All real-time approaches have the disadvantages of high cost and lack of suitability outside a laboratory setting.

\section{Integrative Analysis}

Often, studies that employ high-throughput methods (i.e., omics) consider only one technique. Using multiple techniques in parallel can yield information that is not only mutually supportive but may also be combined into a synergistic model that could be greater than the sum of its parts. There are numerous in vivo interactions between microbial organisms, with both inter- and intra-specific mechanisms that can influence microbial growth or activity. These include crossfeeding between species, biofilm production, quorum sensing, and interspecific competition or "arms race."

Some of these interactions and mechanisms have been characterized for oral diseases such as periodontitis and could potentially be harnessed for understanding and limiting halitosis. For example, crossfeeding microbial species rely on other species for their growth and even survival [152]. Additionally, crossfeeding in the oral cavity is necessary for some pathogens at certain points in their lifecycle. Identifying such relationships among pathogenic or halitotic species might help us better understand the pathogenicity of these dependent species and allow us to target upstream metabolite suppliers for intervention.

Conversely, there is also evidence of repression networks, whereby commensals are found to repress the growth of pathogens [152]. For example, there is in vitro evidence of interspecies competition suppressing a pathogen, although its in vivo applicability remains unknown [153]. Furthermore, there are known effector proteins which can inhibit the development of pathogenic bacteria [154]. If a relationship can be established between the absence of commensals and halitosis, it would open new avenues of treatment, including supplementation of missing commensals in treatment products. Furthermore, quorumsensing molecules, which can influence pathogen activity, may offer a point of intervention for suppressing pathogen growth and invasiveness [155]. Such molecules have been suggested as a method of preventing other biofilm-related diseases in the oral cavity [156].

Using an untargeted metabolomics approach, Seerangaiyan et al. have recently identified 39 metabolites that are putatively associated with $\mathrm{IOH}$ in tongue scrapes from patients [117]. The authors also proposed a list of bacterial classes that might be associated with these metabolites. In vitro experiments on key bacterial species associated with halitosis may also provide an initial understanding of the malodorous compounds that these species produce and eventually the pathways that may be involved in this process [38]. Less-known malodorous compounds than hydrogen sulfide and methyl mercaptansuch as short-chain fatty acids, polyamines, and indole-do play a role in halitosis, although not much knowledge exists on their association with bacteria [157]. Further identification of the bacteria responsible for producing these compounds may help guide new therapeutic strategies. Some authors have reported the benefit of using Annotation of Metabolite Origins via Networks (AMON] [158] as an obvious route for identifying the origin of metabolites through genomic information and for visualizing potential host-microbe interplays when integrating microbiome and metabolome datasets. Mechanistic relationships between microbial communities and host phenotypes can be better understood through integrated analysis of microbiome and metabolome data. 


\section{A FRAMEWORK FOR STUDYING HALITOSIS IN THE CONTEXT OF CS AND ALTERNATIVE TOBACCO PRODUCT USE}

From the body of scientific publications available on halitosis in relation to CS, it is evident that most results were produced from self-assessment evaluations. In general, when a study employed organoleptic assessment and instrument analysis, the results did not correspond with the self-assessment results. Moreover, self-assessment does not provide information on the origin of halitosis, its intensity, or the type of compounds/bacteria that may be responsible for this condition. In the context of comparing the effects of different tobacco/nicotine-containing products on halitosis, it is necessary to have a structured approach that allows us to obtain quantitative results from which we can glean mechanistic insights. In particular, according to the tobacco harm reduction strategy, comparison of alternative nicotine-delivery products with cigarettes is of paramount importance for demonstrating a potential risk reduction $[92,93]$. Any approach for studying these products should, therefore, answer the following questions: (1) What is the impact of alternative nicotine-delivery products on halitosis relative to cigarette smoke; (2) how does the oral bacterial composition differ between cigarette smokers and alternative nicotine-delivery product users in relation to halitosis; and (3) how does the bacterial composition influence the production of halitosisrelated compounds? To answer these questions, we should consider a multilayer framework assessment (Figure 3).

The first layer of the assessment should aim to quickly and cost-effectively prescreen the effects of different product extracts on selected bacterial species with known effects on halitosis in an in vitro system. Such a platform would employ planktonic models or biofilm models, derived from either a single bacterial species, a synthetic community of bacteria, or a natural community of bacteria from tongue scrapings or gingival brushes from different donors. Donors with different grades of halitosis could also be employed, as these are more representative of the halitotic oral microbiome. The types of analyses that can be performed have been demonstrated by Chatzigiannidou et al. who used both synthetic communities and ex vivo samples to shed light on the changes in microbiome composition and viability in response to chlorhexidine [159]. Such methods could be extended to investigate other compounds, as well as investigating the effects of cigarette smoke on bacteria or bacterial communities. Other examples of the use of this platform can be found in the Saad and co-workers publications: they cultivated the biofilm from tongue scrapes of halitosis patients to test efficiently toothpaste and mouthwash formulations in vitro $[160,161]$.

Detection and identification of volatile compounds should be performed in the headspace of the flasks or plates by using MS-based instruments (SIFT-MS, super SESI-HR-MS, HSSPME-GC-MS) that are preferably directly connected to the system $[149,160,162,163]$. A perfusion matrix flow system can maintain a tongue-derived microenvironment which can be conveniently measured or monitored, so that it can be used for studying VOC/VSC production. Such a dynamic system can be maintained for several days, possibly weeks, allowing similarity to in vivo conditions [160]. This model can be used to replicate many of the essential biotic and abiotic features of a real oral biofilm, including ecological stability, and the collective microbial activity that results in VSC production following exposure to different tobacco/nicotine-delivery products, which can be administered at this stage in the form of liquid extracts or aerosols. Nicotine should be used as the reference compound for comparing the products: Cigarette smokers have been shown to adjust their puffing pattern to obtain a certain nicotine concentration in the blood, and the same has been shown in EVP users [164]. This suggests that smokers who switch to an alternative nicotine-delivery product will maintain the same nicotine intake that they had when smoking cigarettes.

The second layer of assessment should focus on exhaled breath analysis. The breath of cigarette smokers and users who have switched to alternative nicotine-delivery products would be analyzed; smokers that quit should be also employed as control group. Real-time breath measurements (Super SESI-HR-MS) can be performed to discover new potential biomarkers of halitosis and to obtain a quantitative measurement of halitosis-related compounds (SIFT-MS or PTR-MS). In addition, off-line GC-MS can be applied as a complementary technique for qualitative and quantitative analysis. Although these measurements can provide a large quantity of data on compounds related to halitosis, they cannot yet predict the degree of odor that a gas mixture may impart to the human nose. Therefore, it is fundamental that evaluation by organoleptic judges is incorporated in the design of a clinical study [113].

The third layer of the investigation should focus on gaining a mechanistic understanding of the causes of halitosis in relation to CS or alternative nicotine-delivery product use. As the bacterial component plays a major role in $\mathrm{IOH}$, as described previously, bacterial samples could be sampled from the tongue surface, supra and sub-gingival plaques, saliva, swabs of oral and nasal cavities, etc.; a multiomics approach that encompasses microbiomics, metabolomics, and proteomics may provide a unique opportunity to define bacterial interactions and detect species-specific metabolite profiles. Finally, this analysis will provide a mechanistic understanding of the different effects of cigarette smoke and alternative nicotine-delivery products on halitosis and allow us to identify the key metabolic/molecular pathways associated with the use of such products. A correlation of these results with the in vitro results from the first layer would be useful to optimize the in vitro methods of bacterial biofilm for research applications.

\section{CLINICAL APPLICABILITY OF THE FRAMEWORK AND PERSPECTIVES}

The hypotheses derived from the experimental work described above could be further validated in a clinical setting where subjects are confined to measure halitosis changes. We propose a randomized, controlled, open-label, three-arm parallel group study to evaluate the effect of switching to alternative 


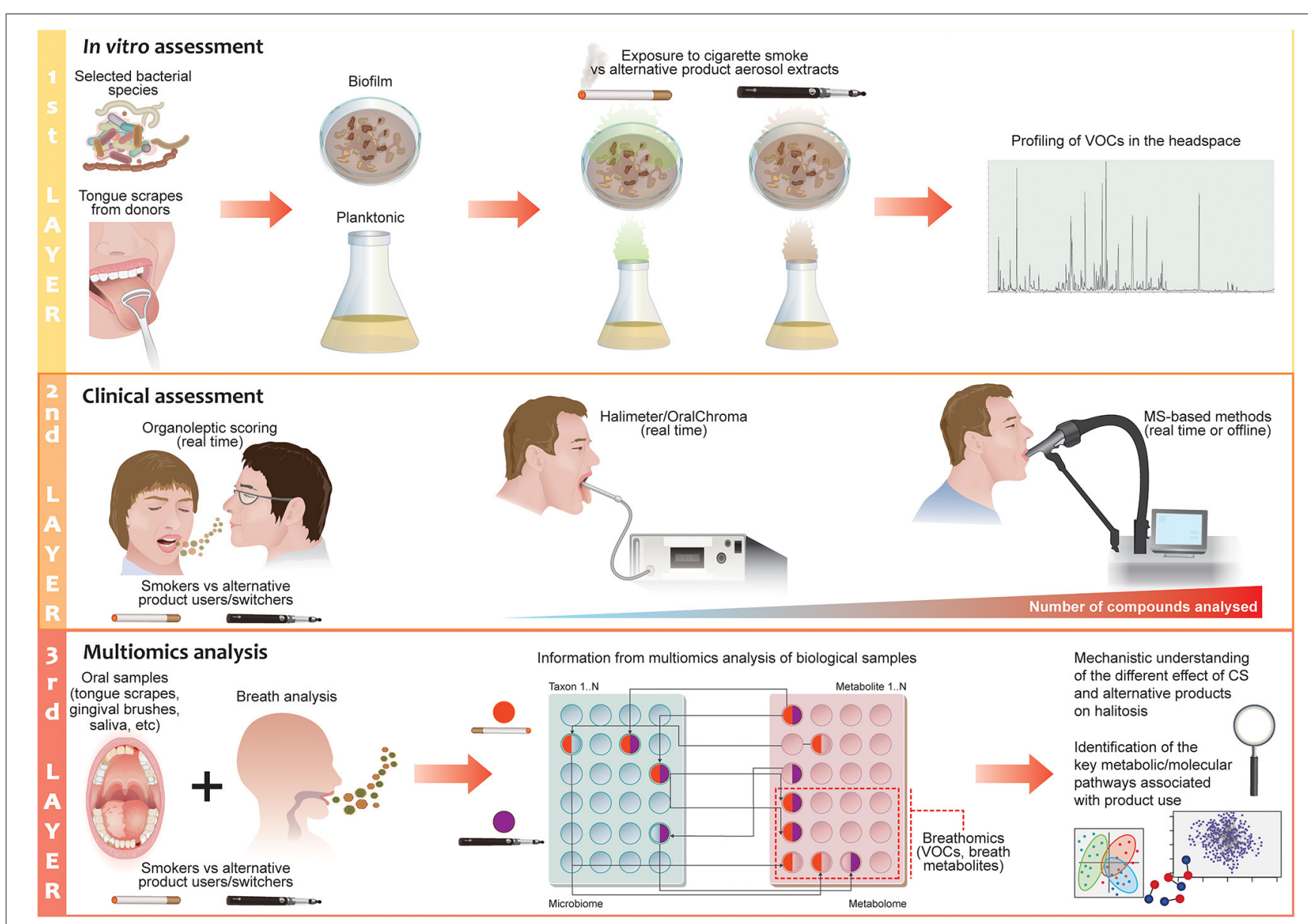

FIGURE 3 | The 3-layer halitosis analysis framework for cigarette smoking and alternative nicotine-delivery product use. The first layer of the proposed framework focuses on testing the effects of the aerosols or liquid fractions of alternative nicotine-delivery products in comparison to cigarette smoke/extract in vitro. Selected bacterial species with known effects on halitosis or tongue scrapes from halitosis patients/donors can be employed in planktonic or biofilm models; the headspace of the flasks or plates is analyzed to detect volatile organic compounds by using MS-based instruments. The second layer focuses on validating the results from the in vitro/ex vivo experiments with clinical measurements of the breath of cigarette smokers and users who have switched to alternative nicotine-delivery products. Real-time breath measurements can be performed with MS-based techniques in a laboratory setting to discover new potential biomarkers of halitosis and provide quantitative measurement of a halitosis-related compound. Evaluation by organoleptic judges is incorporated in the design of the clinical study to define the degree of odor in the subjects. The third layer of the investigation focuses on gaining a mechanistic understanding of the causes of halitosis in relation to CS or alternative nicotine-delivery product use by applying a multiomics approach that encompassed microbiomics and metabolomics.

nicotine-delivery products in healthy smokers suffering from halitosis. The three study arms would comprise a group of healthy smokers who continue to smoke, a group of healthy smokers who switch to alternative nicotine-delivery products, and a group of healthy smokers who quit smoking. The quitting group would be the control, to understand whether the changes in the halitosis profile of the switchers are more similar to the effects of quitting smoking rather than to continuing CS. It may be necessary to conduct a pilot study to estimate the effect size and the required duration for the main study.

The advantage of confinement is that it would allow control over confounding factors that might enhance or mask the detection of halitosis, such as level of hydration, food and beverage consumption, quantity of cigarettes or other products used (see section Assessment of Halitosis). Subjects suffering from caries, periodontitis or gingivitis should be excluded from the study because their condition would make the dominant contribution to halitosis, potentially masking the effects of smoking or switching. Additional information regarding oral and overall health, including age and gender, diet, and the use of antibiotics or other medications could be used to stratify and match subjects among the groups. Organoleptic judges could be employed to score oral malodor at baseline and at the completion of the study.

Devices sensing the presence of VOCs or VSCs (such as the Halimeter) could facilitate the diagnosis of halitosis in addition to traditional organoleptic measurements. MS-based methods could be employed to characterize the VOC and VSC profiles in the breath of the subjects. During the study, microbiome samples could be collected from locations within the oral cavity: 
tongue surface, supra- and subgingival plaques, saliva, and swabs of oral and nasal cavities. Characterization of different microbial population of different oral locations and volatile compounds detected in exhaled breath (layer 3 of the framework described above) would contribute to understanding of changes in oral bacterial populations upon switching from smoking to an alternative nicotine-delivery product.

The findings might provide a better understanding of the causes of halitosis and allow identification of specific biomarkers in oral bacterial/VOC composition that could be targeted in the development of halitosis treatments, not only in smokers and switchers to alternative nicotine-delivery products, but also in all halitosis patients. These findings might ultimately enable the development of personalized solutions based on an individual's microbial and VOC profile.

Although the proposed framework is described in the specific context of the study of IOH produced by oral bacteria, layers 2 and 3 would also be applicable to EOH patients. Besides the interpretation of metabolomics results in relation to the oral microbial population, the metabolic profile of the exhaled breath could also provide important insights into $\mathrm{EOH}$ in patients with known diseases or conditions and lead to the identification of novel biomarkers [110]. In this way, if a metabolic signature in the breath could be related consistently to a certain disease or condition, MS-based methods or sensors could be employed in diagnosis. For example, once validated, portable devices such as NeOse could be used by dentists in daily practice [110] and may become a useful tool to support the organoleptic scoring by judges and ensure inter-study reproducibility of their assessments.

\section{CONCLUSIONS}

CS is a major risk factor for halitosis. For smokers who are not able to quit, alternative nicotine-delivery products like EVPs and HTPs may help reduce the health risks associated with CS. To date, only a few systematic studies have analyzed the effects of CS on halitosis, and none has assessed the effects of EVPs and

\section{REFERENCES}

1. Almas K, Al-Hawish A, Al-Khamis W. Oral hygiene practices, smoking habit, and self-perceived oral malodor among dental students. J Contemp Dent Pract. (2003) 4:77-90. doi: 10.5005/jcdp-4-4-77

2. Seemann R, Filippi A, Michaelis S, Lauterbach S, John HD, Huismann J. Duration of effect of the mouthwash $\mathrm{Cb} 12$ for the treatment of intra-oral halitosis: a double-blind, randomised, controlled trial. J Breath Res. (2016) 10:036002. doi: 10.1088/1752-7155/10/3/036002

3. Alsadhan SA. Self-perceived halitosis and related factors among adults residing in Riyadh, Saudi Arabia. A cross sectional study. Saudi Dent J. (2016) 28:118-23. doi: 10.1016/j.sdentj.2016.06.001

4. Al-Humaidi SF, Dar-Odeh NS, Alnazzawi A, Kutkut A, Hudieb M, AbuHammad O. Volatile sulphur compounds in exhaled air of dental students smoking the waterpipe: a nested case control study. Minerva Stomatol. (2017) 66:157-62. doi: 10.23736/S0026-4970.17.04061-4

5. De Geest S, Laleman I, Teughels W, Dekeyser C, Quirynen M. Periodontal diseases as a source of halitosis: a review of the evidence and treatment approaches for dentists and dental hygienists. Periodontology 2000. (2016) 71:213-27. doi: 10.1111/prd.12111
HTPs on this condition. Self-assessment studies have shown huge limitations owing to the lack of reliability in the participants' judgment. This compels the scientific community to develop a strategy for meaningful assessment of these new products in comparison with cigarettes. In this review, we proposed a 3layer approach that combines the use of the most advanced breath analysis techniques and multiomics analysis to define the interactions between oral bacterial species and their role in halitosis in vitro and in vivo. Such an approach will allow us to compare the effects of different nicotine-delivery products on oral bacteria and quantify their impact on halitosis. Our proposed framework has the potential to quantify and mechanistically address the impact of alternative nicotine-delivery product use in comparison with cigarette smoke on halitosis. The results from such a comprehensive analysis could be used to design treatments for mitigating the potential side effects of alternative nicotine-delivery products on breath odor. Finally, the proposed framework will be an important step for further defining the safety and risks associated with the use of these products for consumers.

\section{AUTHOR CONTRIBUTIONS}

FZ: conceptualization and writing. TZ, JB, PG, and AP: writing and reviewing. NI: conceptualization, writing, and reviewing. $\mathrm{JH}$ : conceptualization and reviewing. All authors contributed to the article and approved the submitted version.

\section{FUNDING}

Philip Morris International is the sole sponsor of this study.

\section{ACKNOWLEDGMENTS}

The authors would like to thank Dr. Sindhoora Gopala Reddy for her scientific editing; Edanz (www.edanz.com) for reviewing a draft of this manuscript; and Samantha Elmhurst for the design of the figures.

6. Chen X, Zhang Y, Lu HX, Feng XP. Factors associated with halitosis in white-collar employees in Shanghai, China. Plos One. (2016) 11:E0155592. doi: 10.1371/journal.pone.0155592

7. Boyanova L. Stress hormone epinephrine (adrenaline) and norepinephrine (noradrenaline) effects on the anaerobic bacteria. Anaerobe. (2017) 44:13-9. doi: 10.1016/j.anaerobe.2017.01.003

8. Wu J, Cannon RD, Ji P, Farella M, Mei L. Halitosis: prevalence, risk factors, sources, measurement and treatment - a review of the literature. Aust Dent J. (2020) 65:4-11. doi: 10.1111/adj.12725

9. Mortazavi H, Rahbani Nobar B, Shafiei S. Drug-Related halitosis: a systematic review. Oral Health Prev Dent. (2020) 18:399-407. doi: 10.3290/j.ohpd.a44679

10. Miyazaki H. Tentative classification of halitosis and its treatment needs. Niigata Dent J. (1999) 32:7-11.

11. Tangerman A, Winkel EG. Extra-oral halitosis: an overview. J Breath Res. (2010) 4:017003. doi: 10.1088/1752-7155/4/1/017003

12. Renvert S, Noack MJ, Lequart C, Roldan S, Laine ML. The underestimated problem of intra-oral halitosis in dental practice: an expert consensus review. Clin Cosmet Investig Dent. (2020) 12:251-62. doi: 10.2147/CCIDE.S2 53765 
13. Porter SR, Scully C, Hegarty AM. An update of the etiology and management of xerostomia. Oral Surg Oral Med Oral Pathol Oral Radiol Endod. (2004) 97:28-46. doi: 10.1016/j.tripleo.2003.07.010

14. Rosenberg M. Clinical assessment of bad breath: current concepts. J Am Dent Assoc. (1996) 127:475-82. doi: 10.14219/jada.archive.1996.0239

15. Quirynen M, Dadamio J, Van Den Velde S, De Smit M, Dekeyser C, Van Tornout M, et al. Characteristics of 2000 patients who visited a halitosis clinic. J Clin Periodontol. (2009) 36:970-5. doi: 10.1111/j.1600-051X.2009.01478.x

16. Allaker RP, Waite RD, Hickling J, North M, Mcnab R, Bosma MP, et al. Topographic distribution of bacteria associated with oral malodour on the tongue. Arch Oral Biol. (2008) 53:S8-12. doi: 10.1016/S0003-9969(08)70003-7

17. Choi KY, Lee BS, Kim JH, Kim JJ, Jang Y, Choi JW, et al. Assessment of volatile sulfur compounds in adult and pediatric chronic tonsillitis patients receiving tonsillectomy. Clin Exp Otorhinolaryngol. (2018) 11:210-5. doi: 10.21053/ceo.2017.01109

18. Laleman I, Dekeyser C, Wylleman A, Teughels W, Quirynen M. The Oralchroma(Tm) Chm-2: a comparison with the Oralchroma(Tm) Chm-1. Clin Oral Investig. (2020) 24:2829-36. doi: 10.1007/s00784-019-03148-9

19. Rani H, Ueno M, Zaitsu T, Furukawa S, Kawaguchi Y. Factors associated with clinical and perceived oral malodor among dental students. J Med Dent Sci. (2015) 62:33-41. doi: 10.11480/620202

20. Tonzetich J. Production and origin of oral malodor: a review of mechanisms and methods of analysis. J Periodontol. (1977) 48:13-20. doi: 10.1902/jop.1977.48.1.13

21. Van Den Velde S, Van Steenberghe D, Van Hee P, Quirynen M. Detection of odorous compounds in breath. J Dent Res. (2009) 88:285-9. doi: $10.1177 / 0022034508329741$

22. Tonzetich J. Oral malodour: an indicator of health status and oral cleanliness. Int Dent J. (1978) 28:309-19.

23. Saad S, Fitzgerald M, Hewett K, Greenman J, Vandeven M, Trivedi HM, et al. Short- and long-term effects of a dentifrice containing dual zinc plus arginine on intra-oral halitosis: improvements in breath quality. J Clin Dent. (2018) 29:A46-54.

24. Mostefa-Saad SB. (2006) The Study Of The Tongue Biofilm And Its Role In Oral Malodour Of Microbial Aetiology, University Of The West Of England.

25. Zhang S, Bian H, Li X, Wu H, Bi Q, Yan Y, et al. Hydrogen sulfide promotes cell proliferation of oral cancer through activation of the Cox2/Akt/Erk1/2 axis. Oncol Rep. (2016) 35:2825-32. doi: 10.3892/or.2016.4691

26. Karpinski TM. Role of oral microbiota in cancer development. Microorganisms. (2019) 7:20. doi: 10.3390/microorganisms7010020

27. Yalcin Yeler D, Aydin M, Hocaoglu PT, Koraltan M, Ozdemir H, Kotil $\mathrm{T}$, et al. Ultrastructural changes in epithelial cells of rats exposed to low concentration of hydrogen sulfide for 50 days. Ultrastruct Pathol. (2016) 40:351-7. doi: 10.1080/01913123.2016.1234530

28. Dadamio J, Van Tornout M, Van Den Velde S, Federico R, Dekeyser C, Quirynen M. A novel and visual test for oral malodour: first observations. J Breath Res. (2011) 5:046003. doi: 10.1088/1752-7155/5/4/046003

29. Mok SF, Karuthan C, Cheah YK, Ngeow WC, Rosnah Z, Yap SF, et al. The oral microbiome community variations associated with normal, potentially malignant disorders and malignant lesions of the oral cavity. Malays J Pathol. (2017) 39:1-15.

30. Krishnan K, Chen T, Paster BJ. A practical guide to the oral microbiome and its relation to health and disease. Oral Dis. (2017) 23:276-86. doi: 10.1111/odi.12509

31. Seerangaiyan K, Van Winkelhoff AJ, Harmsen HJM, Rossen JWA, Winkel EG. The tongue microbiome in healthy subjects and patients with intraoral halitosis. J Breath Res. (2017) 11:036010. doi: 10.1088/1752-7163/ aa7c24

32. Seerangaiyan K, Juch F, Winkel EG. Tongue coating: its characteristics and role in intra-oral halitosis and general health-a review. J Breath Res. (2018) 12:034001. doi: 10.1088/1752-7163/aaa3al

33. Ye W, Zhang Y, He M, Zhu C, Feng XP. Relationship of tongue coating microbiome on volatile sulfur compounds in healthy and halitosis adults. $J$ Breath Res. (2019) 14:016005. doi: 10.1088/1752-7163/ab47b4

34. Kazor CE, Mitchell PM, Lee AM, Stokes LN, Loesche WJ, Dewhirst FE, et al. Diversity of bacterial populations on the tongue dorsa of patients with halitosis and healthy patients. J Clin Microbiol. (2003) 41:558-63. doi: 10.1128/JCM.41.2.558-563.2003

35. Ren W, Xun Z, Wang Z, Zhang Q, Liu X, Zheng H, et al. Tongue coating and the salivary microbial communities vary in children with halitosis. Sci Rep. (2016) 6:24481. doi: 10.1038/srep24481

36. Bernardi S, Continenza MA, Al-Ahmad A, Karygianni L, Follo M, Filippi A, et al. Streptococcus spp. and fusobacterium nucleatum in tongue dorsum biofilm from halitosis patients: a Fluorescence In Situ Hybridization (FISH) and Confocal Laser Scanning Microscopy (CLSM) study. New Microbiol. (2019) 42:108-13.

37. Bernardi S, Karygianni L, Filippi A, Anderson AC, Zurcher A, Hellwig E, et al. Combining culture and culture-independent methods reveals new microbial composition of halitosis patients' tongue biofilm. Microbiologyopen. (2020) 9:E958. doi: 10.1002/mbo3.958

38. Takeshita T, Suzuki N, Nakano Y, Yasui M, Yoneda M, Shimazaki $\mathrm{Y}$, et al. Discrimination of the oral microbiota associated with high hydrogen sulfide and methyl mercaptan production. Sci Rep. (2012) 2:215. doi: $10.1038 /$ srep 00215

39. Washio J, Sato T, Koseki T, Takahashi N. Hydrogen sulfide-producing bacteria in tongue biofilm and their relationship with oral malodour. J Med Microbiol. (2005) 54:889-95. doi: 10.1099/jmm.0.46118-0

40. Takeshita T, Suzuki N, Nakano Y, Shimazaki Y, Yoneda M, Hirofuji T, et al. Relationship between oral malodor and the global composition of indigenous bacterial populations in saliva. Appl Environ Microbiol. (2010) 76:2806-14. doi: 10.1128/AEM.02304-09

41. Veloso DJ, Abrao F, Martins CHG, Bronzato JD, Gomes B, Higino JS, et al. Potential antibacterial and anti-halitosis activity of medicinal plants against oral bacteria. Arch Oral Biol. (2020) 110:104585. doi: 10.1016/j.archoralbio.2019.104585

42. Silva MF, Cademartori MG, Leite FRM, Lopez R, Demarco FF, Nascimento GG. Is periodontitis associated with halitosis? A systematic review and meta-regression analysis. J Clin Periodontol. (2017) 44:1003-9. doi: $10.1111 /$ jcpe. 12786

43. Pham TA, Ueno M, Zaitsu T, Takehara S, Shinada K, Lam PH, et al. Clinical trial of oral malodor treatment in patients with periodontal diseases. $J$ Periodontal Res. (2011) 46:722-9. doi: 10.1111/j.1600-0765.2011.01395.x

44. Niederauer AJ, Guimaraes RA, Oliveira KL, Pires AR Jr, Demasi AP, Ferreira $\mathrm{HH}$, et al. $\mathrm{H}_{2} \mathrm{~S}$ in periodontal immuneinflammatory response and bone loss: a study in rats. Acta Odontol Latinoam. (2019) 32:164-71.

45. Silva MF, Nascimento GG, Leite FRM, Horta BL, Demarco FF. Periodontitis and self-reported halitosis among young adults from the 1982 pelotas birth cohort. Oral Dis. (2020) 26:843-6. doi: 10.1111/odi.13286

46. Suzuki N, Yoneda M, Takeshita T, Hirofuji T, Hanioka T. Induction and inhibition of oral malodor. Mol Oral Microbiol. (2019) 34:85-96. doi: 10.1111/omi.12259

47. Codipilly D, Kleinberg I. Generation of indole/skatole during malodor formation in the salivary sediment model system and initial examination of the oral bacteria involved. J Breath Res. (2008) 2:017017. doi: 10.1088/1752-7155/2/1/017017

48. Al-Atrooshi BA, Al-Rawi AS. Oral halitosis and oral hygiene practices among dental students. J Baghdad College Dentistry. (2007) 19:72-6.

49. Curtis MA, Diaz PI, Van Dyke TE. The role of the microbiota in periodontal disease. Periodontol 2000. (2020) 83:14-25. doi: 10.1111/prd.12296

50. Jiang Y, Zhou X, Cheng L, Li M. The impact of smoking on subgingival microflora: from periodontal health to disease. Front Microbiol. (2020) 11:66. doi: $10.3389 /$ fmicb. 2020.00066

51. Ilankizhai R, Leelavathi L. Comparison of oral microbiota among smokers and non-smokers-a pilot study. Drug Invention Today. (2018) 10.

52. Grover N, Sharma J, Sengupta S, Singh S, Singh N, Kaur H. Long-Term effect of tobacco on unstimulated salivary Ph. J Oral Maxillofac Pathol. (2016) 20:16-9. doi: 10.4103/0973-029X.180907

53. Mason MR, Preshaw PM, Nagaraja HN, Dabdoub SM, Rahman A, Kumar PS. The subgingival microbiome of clinically healthy current and never smokers. ISME J. (2015) 9:268-72. doi: 10.1038/ismej.2014.114

54. Wu J, Li M, Huang R. The effect of smoking on caries-related microorganisms. Tob Induc Dis. (2019) 17:32. doi: 10.18332/tid/105913

55. Sato N, Kakuta M, Hasegawa T, Yamaguchi R, Uchino E, Kobayashi W, et al. Metagenomic analysis of bacterial species in tongue microbiome 
of current and never smokers. NPJ Biofilms Microbiomes. (2020) 6:11. doi: 10.1038/s41522-020-0121-6

56. Hampelska K, Jaworska MM, Babalska ZL, Karpinski TM. The role of oral microbiota in intra-oral halitosis. J Clin Med. (2020) 9:2484. doi: $10.3390 / \mathrm{jcm} 9082484$

57. Ma Q, Zhang X, Qu Y. Biodegradation and biotransformation of indole: advances and perspectives. Front Microbiol. (2018) 9:2625. doi: $10.3389 /$ fmicb.2018.02625

58. Al-Zyoud W, Hajjo R, Abu-Siniyeh A, Hajjaj S. Salivary microbiome and cigarette smoking: a first of its kind investigation in Jordan. Int $J$ Environ Res Public Health. (2019) 17:256. doi: 10.3390/ijerph17010256

59. Okazawa Y, Hinode D, Yoshioka M, Doi T, Nakae H, Sogawa $\mathrm{Y}$, et al. Comparison of oral malodor and oral microbiome in smokers and non-smokers. Jpn J Smoking Control Sci. (2017) 11:1-9. doi: 10.32213/jascs.vol.11.06_1

60. Patrounova V, Yoon JH, Schmitz JM, Nguyen K, Alaniz J, Yammine L. Combustible and electronic cigarette use among patients at a large academic dental school clinic: a preimplementation needs assessment survey. J Am Dent Assoc. (2020) 151:510-8. doi: 10.1016/j.adaj.2020.03.016

61. Lisetska IS. Study of the Prevalence of Halitosis in Young People Who Smoke (2020). Available online at: http://rep.bsmu.by/bitstream/handle/ BSMU/29086/92_94.pdf? sequence $=1$ \&isAllowed $=y$

62. Thielen A, Klus H, Muller L. Tobacco smoke: unraveling a controversial subject. Exp Toxicol Pathol. (2008) 60:141-56. doi: 10.1016/j.etp.2008.01.014

63. Borgerding M, Klus H. Analysis of complex mixtures-cigarette smoke. Exp Toxicol Pathol. (2005) 57:43-73. doi: 10.1016/j.etp.2005.05.010

64. Rosenberg M, Mcculloch CA. Measurement of oral malodor: current methods and future prospects. J Periodontol. (1992) 63:776-82. doi: 10.1902/jop.1992.63.9.776

65. Al-Ansari JM, Boodai H, Al-Sumait N, Al-Khabbaz AK, Al-Shammari KF, Salako N. Factors associated with self-reported halitosis in Kuwaiti patients. J Dent. (2006) 34:444-9. doi: 10.1016/j.jdent.2005.10.002

66. Alqahtani F, Alqhtani N, Divakar DD, Shetty SB, Shetty B, Alkhtani F. Selfrated peri-implant oral symptoms and clinicoradiographic characteristics in Narghile-smokers, cigarette-smokers, and nonsmokers with peri-implantitis. Clin Implant Dent Relat Res. (2019) 21:1235-40. doi: 10.1111/cid. 12864

67. Al-Zahrani MS, Zawawi KH, Austah ON, Al-Ghamdi HS. Self reported halitosis in relation to glycated hemoglobin level in diabetic patients. Open Dent J. (2011) 5:154-7. doi: 10.2174/1874210601105010154

68. Ayo-Yusuf OA, Postma TC, Van Wyk C. Clinical correlates of oral malodour in a population of patients attending a preventive clinic in Pretoria, South Africa. SADJ. (2011) 66:328-31.

69. Babazadeh S, Yazdani R, Pakdaman A, Kambakhsh SM. Normative and Subjective Oral Health Evaluation among Smoker and non-Smoker Adolescents of Qazvin, Iran, in 2015. Iran Red Crescent Med J. (2017) 19. doi: $10.5812 /$ ircmj. 58673

70. Eldarrat AH. Influence of oral health and lifestyle on oral malodour. Int Dent J. (2011) 61:47-51. doi: 10.1111/j.1875-595X.2011.00010.x

71. Jiun I, Siddik S, Malik SN, Tin-Oo MM, Alam MK, Khan M. Association between oral hygiene status and halitosis among smokers and nonsmokers. Oral Health Prev Dent. (2015) 13:395-405. doi: 10.3290/j.ohpd. a33920

72. Lee HJ, Kim HM, Kim N, Oh JC, Jo HJ, Lee JT, et al. Association between halitosis diagnosed by a questionnaire and halimeter and symptoms of gastroesophageal reflux disease. J Neurogastroenterol Motil. (2014) 20:48390. doi: $10.5056 /$ jnm 14052

73. Rech RS, Santos KW, Maahs MA, Vidor DC. Masticatory changes as a result of oral disorders in smokers. Int Arch Otorhinolaryngol. (2014) 18:369-75. doi: 10.1055/s-0034-138584

74. Romano F, Perotto S, Bianco L, Parducci F, Mariani GM, Aimetti M. SelfPerception of periodontal health and associated factors: a cross-sectional population-based study. Int J Environ Res Public Health. (2020) 17:2758. doi: $10.3390 /$ ijerph 17082758

75. Saadaldina SA, Eldwakhly E, Alnazzawi AA, Alharbi RA, Alghamdi BK, Abu Hammad OA, et al. Awareness and practice of oral health measures in medina, Saudi Arabia: an observational study. Int J Environ Res Public Health. (2020) 17:9112. doi: 10.3390/ijerph17239112
76. Şanli A, Bekmez E, Yildiz G, Erdoğan BA, Yilmaz HB, Altin G. Relationship between smoking and otorhinolaryngological symptoms. Kulak Burun Bogaz Ihtis Derg. (2016) 26:28-33. doi: 10.5606/kbbihtisas.2016.87059

77. Struch F, Schwahn C, Wallaschofski H, Grabe HJ, Völzke H, Lerch $\mathrm{MM}$, et al. Self-reported halitosis and gastro-esophageal reflux disease in the general population. J Gen Intern Med. (2008) 23:260-6. doi: 10.1007/s11606-007-0486-8

78. Setia S, Pannu P, Gambhir RS, Galhotra V, Ahluwalia P, Sofat A. Correlation of oral hygiene practices, smoking and oral health conditions with self perceived halitosis amongst undergraduate dental students. J Nat Sci Biol Med. (2014) 5:67-72. doi: 10.4103/0976-9668.127291

79. Tubaishat RS, Malkawi ZA, Albashaireh ZS. The influence of different factors on the oral health status of smoking and nonsmoking adults. J Contemp Dent Pract. (2013) 14:731-7. doi: 10.5005/jp-journals-10024-1392

80. Barik A, Rai RK, Chowdhury A. Tobacco use and self-reported morbidity among rural Indian adults. Prim Health Care Res Dev. (2016) 17:514-23. doi: $10.1017 /$ S146342361600013X

81. Bornstein MM, Kislig K, Hoti BB, Seemann R, Lussi A. Prevalence of halitosis in the population of the city of Bern, Switzerland: a study comparing self-reported and clinical data. Eur J Oral Sci. (2009) 117:261-7. doi: $10.1111 / j .1600-0722.2009 .00630 . x$

82. Bornstein MM, Stocker BL, Seemann R, Bürgin WB, Lussi A. Prevalence of halitosis in young male adults: a study in swiss army recruits comparing self-reported and clinical data. J Periodontol. (2009) 80:24-31. doi: 10.1902/jop.2009.080310

83. Kayombo CM, Mumghamba EG. Self-reported halitosis in relation to oral hygiene practices, oral health status, general health problems, and multifactorial characteristics among workers in Ilala and Temeke Municipals, Tanzania. Int J Dent. (2017) 2017:8682010. doi: $10.1155 / 2017 / 8682010$

84. Kim SY, Sim S, Kim SG, Park B, Choi HG. Prevalence and associated factors of subjective halitosis in korean adolescents. PLoS One. (2015) 10:e0140214. doi: 10.1371/journal.pone.0140214

85. Miyazaki H, Sakao S, Katoh Y, Takehara T. Correlation between volatile sulphur compounds and certain oral health measurements in the general population. J Periodontol. (1995) 66:679-84. doi: 10.1902/jop.1995.66.8.679

86. Khaira N, Palmer RM, Wilson RF, Scott DA, Wade WG. Production of volatile sulphur compounds in diseased periodontal pockets is significantly increased in smokers. Oral Dis. (2000) 6:371-5. doi: 10.1111/j.1601-0825.2000.tb00129.x

87. Santos A, Pascual A, Llopis J, Giner L, Kim DM, Levi P, et al. Self-reported oral hygiene habits in smokers and nonsmokers diagnosed with periodontal disease. Oral Health Prev Dent. (2015) 13:245-51. doi: 10.3290/j.ohpd.a34248

88. Wu J, Peters BA, Dominianni C, Zhang Y, Pei Z, Yang L, et al. Cigarette smoking and the oral microbiome in a large study of American adults. ISME J. (2016) 10:2435-46. doi: 10.1038/ismej.2016.37

89. Watt R, Daly B, Kay SEE. Prevention. Part 1: smoking cessation advice within the general dental practice. Br Dent J. (2003) 194:665-8. doi: 10.1038/sj.bdj.4810266

90. Andritsou M, Schoretsaniti S, Litsiou E, Saltagianni V, Konstadara K, Spiliotopoulou A, et al. Success rates are correlated mainly to completion of a smoking cessation program. Eur Respiratory Soc. (2016) 48:PA4599. doi: 10.1183/13993003.congress-2016.PA4599

91. Ashley D, Burns D, Djordjevic M, Dybing E, Gray N, Hammond S, et al. The scientific basis of tobacco product regulation. World Health Organ Tech Rep Ser. (2008) 1-277.

92. Amos A, Arnott D, Aveyard P, Bauld L, Bogdanovica I, Britton J, et al. Nicotine Without Smoke: Tobacco Harm, Reduction. Royal College of Physicians (2016).

93. Cox S, Dawkins L. Global and local perspectives on tobacco harm reduction: what are the issues and where do we go from here? Harm Reduct J. (2018) 15:32. doi: 10.1186/s12954-018-0239-5

94. Hua M, Sadah S, Hristidis V, Talbot P. Health effects associated with electronic cigarette use: automated mining of online forums. J Med Internet Res. (2020) 22:E15684. doi: 10.2196/15684

95. Soule EK, Bode KM, Desrosiers AC, Guy M, Breland A, Fagan P. Userperceived negative respiratory symptoms associated with electronic cigarette use. Nicotine Tob Res. (2020) 22:S45-53. doi: 10.1093/ntr/ntaa179 
96. Seemann R, Bizhang M, Djamchidi C, Kage A, Nachnani S. The proportion of pseudo-halitosis patients in a multidisciplinary breath malodour consultation. Int Dent J. (2006) 56:77-81. doi: 10.1111/j.1875-595X.2006.tb00077.x

97. Pushalkar S, Paul B, Li Q, Yang J, Vasconcelos R, Makwana S, et al. Electronic cigarette aerosol modulates the oral microbiome and increases risk of infection. iScience. (2020) 23:100884. doi: 10.1016/j.isci.2020.100884

98. Chopyk J, Bojanowski CM, Shin J, Moshensky A, Fuentes AL, Bonde SS, et al. Compositional differences in the oral microbiome of e-cigarette users. Front Microbiol. (2021) 12:599664. doi: 10.3389/fmicb.2021.599664

99. Sahu S, Nagarajappa R, Sahoo KK, Naik D, Sahu N. Vaping: realities in its effect on oral health. Indian J Forensic Med Toxicol. (2020) 14:8723-6. doi: 10.37506/ijfmt.v14i4.13079

100. Patel J, Kulkarni S, Doshi D, Reddy P, Reddy S, Srilatha A. Association between social anxiety with oral hygiene status and tongue coating among patients with subjective halitosis. J Dent Hyg. (2017) 91:55-63.

101. Bollen CM, Beikler T. Halitosis: the multidisciplinary approach. Int J Oral Sci. (2012) 4:55-63. doi: 10.1038/ijos.2012.39

102. Dayma A, Jain M, Saxena V. Validation of organoleptics and instrumental measurement for halitosis among patient with malodour. J Dent Health Oral Disord Ther. (2020) 11:6-10. doi: 10.15406/jdhodt.2020.11.00511

103. Scully C, El-Maaytah M, Porter SR, Greenman J. Breath odor: etiopathogenesis, assessment and management. Eur J Oral Sci. (1997) 105:287-93. doi: 10.1111/j.1600-0722.1997.tb00242.x

104. Calil CM, Marcondes FK. Influence of anxiety on the production of oral volatile sulfur compounds. Life Sci. (2006) 79:660-4. doi: 10.1016/j.lfs.2006.02.010

105. Gaugg MT, Nussbaumer-Ochsner Y, Bregy L, Engler A, Stebler N, Gaisl T, et al. Real-time breath analysis reveals specific metabolic signatures of copd exacerbations. Chest. (2019) 156:269-76. doi: 10.1016/j.chest.2018.12.023

106. Hansanugrum A, Barringer SA. Effect of milk on the deodorization of malodorous breath after garlic ingestion. J Food Sci. (2010) 75:C549-58. doi: 10.1111/j.1750-3841.2010.01715.x

107. Tamaki K, Tamaki T, Yamazaki T. Studies on the deodorization by mushroom (Agaricus Bisporus) extract of garlic extract-induced oral malodor. J Nutr Sci Vitaminol. (2007) 53:277-86. doi: 10.3177/jnsv.53.277

108. Mirondo R, Barringer S. Deodorization of garlic breath by foods, and the role of polyphenol oxidase and phenolic compounds. J Food Sci. (2016) 81:C2425-30. doi: 10.1111/1750-3841.13439

109. Munch R, Barringer SA. Deodorization of garlic breath volatiles by food and food components. J Food Sci. (2014) 79:C526-33. doi: 10.1111/1750-3841.12394

110. Nakhleh MK, Quatredeniers M, Haick H. Detection of halitosis in breath: between the past, present, and future. Oral Dis. (2018) 24:685-95. doi: 10.1111/odi.12699

111. Schmidt J, Krause F, Haak R. Halitosis: measurement in daily practice. Quintessence Int. (2015) 46:633-41. doi: 10.3290/j.qi.a34134

112. Slimani S, Bultel E, Cubizolle T, Herrier C, Rousselle T, Livache T. Opto-electronic nose coupled to a silicon micro pre-concentrator device for selective sensing of flavored waters. Chemosensors. (2020) 8:60. doi: $10.3390 /$ chemosensors 8030060

113. Saad S, Beauchamp J. A spate of bad breath: report from the international conference on oral malodour (2019). J Breath Res. (2020) 14:040201. doi: 10.1088/1752-7163/ab8d8a

114. Bicak DA. A current approach to halitosis and oral malodor- a mini review. Open Dent J. (2018) 12:322-30. doi: 10.2174/1874210601812010322

115. Gibson G. A Primer Of Human Genetics, Sinauer Associates, Incorporated, Publishers (2015).

116. Civelek M, Lusis AJ. Systems genetics approaches to understand complex traits. Nat Rev Genet. (2014) 15:34-48. doi: 10.1038/nrg3575

117. Seerangaiyan K, Maruthamuthu M, Van Winkelhoff AJ, Winkel EG. Untargeted metabolomics of the bacterial tongue coating of intra-oral halitosis patients. J Breath Res. (2019) 13:046010. doi: 10.1088/1752-7163/ab334e

118. Giaouris E, Heir E, Desvaux M, Hebraud M, Moretro T, Langsrud $\mathrm{S}$, et al. Intra- and inter-species interactions within biofilms of important foodborne bacterial pathogens. Front Microbiol. (2015) 6:841. doi: $10.3389 /$ fmicb. 2015.00841
119. Foo LH, Balan P, Pang LM, Laine ML, Seneviratne CJ. Role of the oral microbiome, metabolic pathways, and novel diagnostic tools in intra-oral halitosis: a comprehensive update. Crit Rev Microbiol. (2021) 47:359-75. doi: 10.1080/1040841X.2021.1888867

120. Kamaraj DR, Bhushan KS, Laxman VK, Mathew J. Detection of odoriferous subgingival and tongue microbiota in diabetic and nondiabetic patients with oral malodor using polymerase chain reaction. Indian J Dental Res. (2011) 22:260. doi: 10.4103/0970-9290.84301

121. Kamaraj D, Bhushan KS. An evaluation of microbial profile in halitosis with tongue coating using pcr (polymerase chain reaction)-A clinical and microbiological study. J Clin Diagnostic Res. (2014) 8:263. doi: 10.7860/JCDR/2014/6213.3856

122. Park SN, Lim YK, Kook JK. Development of quantitative real-time PCR primers for detecting 42 oral bacterial species. Arch Microbiol. (2013) 195:473-82. doi: 10.1007/s00203-013-0896-4

123. Nakano Y, Takeshita T, Kamio N, Shiota S, Shibata Y, Suzuki N, et al. Supervised machine learning-based classification of oral malodor based on the microbiota in saliva samples. Artif Intell Med. (2014) 60:97-101. doi: 10.1016/j.artmed.2013.12.001

124. Yang F, Huang S, He T, Catrenich C, Teng F, Bo C, et al. Microbial basis of oral malodor development in humans. J Dent Res. (2013) 92:1106-12. doi: $10.1177 / 0022034513507065$

125. Dewhirst FE, Chen T, Izard J, Paster BJ, Tanner AC, Yu WH, et al. The human oral microbiome. J Bacteriol. (2010) 192:5002-17. doi: 10.1128/JB.00542-10

126. Zhang XW, Li QH, Dou JJ. Mass spectrometry-based metabolomics in health and medical science: a systematic review. Rsc Adv. (2020) 10:3092-104. doi: 10.1039/C9RA08985C

127. Beale DJ, Jones OA, Karpe AV, Dayalan S, Oh DY, Kouremenos KA, et al. A review of analytical techniques and their application in disease diagnosis in breathomics and salivaomics research. Int J Mol Sci. (2016) 18:24. doi: 10.3390/ijms18010024

128. Gowda GA, Djukovic D. Overview of mass spectrometry-based metabolomics: opportunities and challenges. Methods Mol Biol. (2014) 1198:3-12. doi: 10.1007/978-1-4939-1258-2_1

129. Al-Kateb H, De Lacy Costello B, Ratcliffe N. An investigation of volatile organic compounds from the saliva of healthy individuals using headspace-Trap/Gc-Ms. J Breath Res. (2013) 7:036004. doi: 10.1088/1752-7155/7/3/036004

130. Van Den Velde S, Nevens F, Van Hee P, Van Steenberghe D, Quirynen M. Gc-Ms Analysis of breath odor compounds in liver patients. J Chromatogr B Analyt Technol Biomed Life Sci. (2008) 875:344-8. doi: 10.1016/j.jchromb.2008.08.031

131. Jo JK, Seo SH, Park SE, Kim HW, Kim EJ, Na CS, et al. Identification of salivary microorganisms and metabolites associated with halitosis. Metabolites. (2021) 11:362. doi: 10.3390/metabo11060362

132. Monedeiro F, Milanowski M, Ratiu IA, Zmyslowski H, Ligor T, Buszewski B. Voc profiles of saliva in assessment of halitosis and submandibular abscesses using Hs-Spme-Gc/Ms technique. Molecules. (2019) 24:2977. doi: 10.3390/molecules24162977

133. Fukui M, Hinode D, Yokoyama M, Yoshioka M, Kataoka K, Ito HO. Levels of salivary stress markers in patients with anxiety about halitosis. Arch Oral Biol. (2010) 55:842-7. doi: 10.1016/j.archoralbio.2010.07.014

134. Zappacosta B, Manni A, Persichilli S, Boari A, Scribano D, Minucci A, et al. Salivary thiols and enzyme markers of cell damage in periodontal disease. Clin Biochem. (2007) 40:661-5. doi: 10.1016/j.clinbiochem.2007. 01.011

135. Rattray NJ, Hamrang Z, Trivedi DK, Goodacre R, Fowler SJ. Taking your breath away: metabolomics breathes life in to personalized medicine. Trends Biotechnol. (2014) 32:538-48. doi: 10.1016/j.tibtech.2014.08.003

136. Kuo TC, Tan CE, Wang SY, Lin OA, Su BH, Hsu MT, et al. Human breathomics database. Database. (2020) 2020:baz139. doi: 10.1093/database/baz139

137. Boots AW, Van Berkel JJ, Dallinga JW, Smolinska A, Wouters EF, Van Schooten FJ. The versatile use of exhaled volatile organic compounds in human health and disease. J Breath Res. (2012) 6:027108. doi: 10.1088/1752-7155/6/2/027108

138. Cumeras R, Correig X. Volatile Organic Compound Analysis In Biomedical Diagnosis Applications. CRC Press. (2018). doi: 10.1201/9780429433580 
139. Kabir E, Raza N, Kumar V, Singh J, Tsang YF, Lim DK, et al. Recent advances in nanomaterial-based human breath analytical technology for clinical diagnosis and the way forward. Chem. (2019) 5:3020-57. doi: 10.1016/j.chempr.2019.08.004

140. Lawal O, Ahmed WM, Nijsen TM, Goodacre R, Fowler SJ. Exhaled breath analysis: a review of 'breath-taking'methods for off-line analysis. Metabolomics. (2017) 13:1-16. doi: 10.1007/s11306-017-1241-8

141. Van Den Velde S, Quirynen M, Van Hee P, Van Steenberghe. D. Halitosis associated volatiles in breath of healthy subjects. $J$ Chromatogr B Analyt Technol Biomed Life Sci. (2007) 853:54-61. doi: 10.1016/j.jchromb.2007.02.048

142. Bregy L, Nussbaumer-Ochsner Y, Sinues PML, García-Gómez D, Suter $\mathrm{Y}$, et al. Real-time mass spectrometric identification of metabolites characteristic of chronic obstructive pulmonary disease in exhaled breath. Clinical Mass Spectrometr. (2018) 7:29-35. doi: 10.1016/j.clinms.2018. 02.003

143. Singh KD, Del Miguel GV, Gaugg MT, Ibanez AJ, Zenobi R, Kohler M, et al. Translating secondary electrospray ionization-high-resolution mass spectrometry to the clinical environment. J Breath Res. (2018) 12:027113. doi: 10.1088/1752-7163/aa9ee3

144. Garcia-Gomez D, Martinez-Lozano Sinues P, Barrios-Collado C, Vidal-DeMiguel G, Gaugg M, Zenobi R. Identification Of 2-Alkenals, 4-hydroxy2-alkenals, and 4-hydroxy-2,6-alkadienals in exhaled breath condensate by uhplc-hrms and in breath by real-time hrms. Anal Chem. (2015) 87:3087-93. doi: 10.1021/ac504796p

145. Hansel A, Jordan A, Holzinger R, Prazeller P, Vogel W, Lindinger W. Proton transfer reaction mass spectrometry: on-line trace gas analysis at the Ppb level. Int J Mass Spectrometr Ion Process. (1995) 149:609-19. doi: 10.1016/0168-1176(95)04294-U

146. Herbig J, Muller M, Schallhart S, Titzmann T, Graus M, Hansel A. On-line breath analysis with Ptr-tof. J Breath Res. (2009) 3:027004. doi: 10.1088/1752-7155/3/2/027004

147. Smith D, Spanel P. Status of selected ion flow tube ms: accomplishments and challenges in breath analysis and other areas. Bioanalysis. (2016) 8:1183-201. doi: 10.4155/bio-2016-0038

148. Bruderer T, Gaisl T, Gaugg MT, Nowak N, Streckenbach B, Muller S, et al. On-line analysis of exhaled breath focus review. Chem Rev. (2019) 119:10803-28. doi: 10.1021/acs.chemrev.9b00005

149. Bregy L, Muggler AR, Martinez-Lozano Sinues P, Garcia-Gomez D, Suter Y, Belibasakis GN, et al. Differentiation of oral bacteria in vitro cultures and human saliva by secondary electrospray ionization - mass spectrometry. Sci Rep. (2015) 5:15163. doi: 10.1038/srep15163

150. Smith D, Spanel P, Herbig J, Beauchamp J. Mass spectrometry for real-time quantitative breath analysis. J Breath Res. (2014) 8:027101. doi: 10.1088/1752-7155/8/2/027101

151. Jordan A, Haidacher S, Hanel G, Hartungen E, Märk L, Seehauser H, et al. A high resolution and high sensitivity proton-transfer-reaction time-of-flight mass spectrometer (Ptr-Tof-Ms). Int J Mass Spectrometr. (2009) 286:122-8. doi: 10.1016/j.ijms.2009.07.005

152. Stacy A, Everett J, Jorth P, Trivedi U, Rumbaugh KP, Whiteley M. Bacterial fight-and-flight responses enhance virulence in a polymicrobial infection. Proc Natl Acad Sci USA. (2014) 111:7819-24. doi: 10.1073/pnas.140058 6111

153. Miyoshi T, Oge S, Nakata S, Ueno Y, Ukita H, Kousaka R, et al. Gemella haemolysans inhibits the growth of the periodontal pathogen Porphyromonas gingivalis. Sci Rep. (2021) 11:11742. doi: 10.1038/s41598-021-91267-3

154. Christopher AB, Arndt A, Cugini C, Davey ME. A streptococcal effector protein that inhibits porphyromonas gingivalis biofilm development. Microbiology. (2010) 156:3469. doi: 10.1099/mic.0.042671-0

155. Jang YJ, Choi YJ, Lee SH, Choi K. Autoinducer 2 of fusobacterium nucleatum as a target molecule to inhibit biofilm formation of periodontopathogens. Archives Oral Biol. (2013) 58:17-27. doi: 10.1016/j.archoralbio.2012.04.016

156. Muras A, Mallo N, Otero-Casal P, Pose-Rodríguez JM, Otero A. Quorum sensing systems as a new target to prevent biofilm-related oral diseases. Oral Dis. (2020). doi: 10.1111/odi.13689. [Epub ahead of print].

157. Scully C, Greenman J. Halitology (breath odour: aetiopathogenesis and management). Oral Dis. (2012) 18:333-45. doi: 10.1111/j.1601-0825.2011.01890.x

158. Shaffer M, Thurimella K, Quinn K, Doenges K, Zhang X, Bokatzian S, et al. Amon: annotation of metabolite origins via networks to integrate microbiome and metabolome data. BMC Bioinformat. (2019) 20:614. doi: 10.1186/s12859-019-3176-8

159. Chatzigiannidou I, Teughels W, Van De Wiele T, Boon N. Oral biofilms exposure to chlorhexidine results in altered microbial composition and metabolic profile. NPJ Biofilms Microbiomes. (2020) 6:13. doi: 10.1038/s41522-020-0124-3

160. Saad S, Hewett K, Greenman J. Use of an in vitro flat-bed biofilm model to measure biologically active anti-odour compounds. Appl Microbiol Biotechnol. (2013) 97:7865-75. doi: 10.1007/s00253-013-5084-6

161. Saad S, Hewett K, Greenman J. Effect of mouth-rinse formulations on oral malodour processes in tongue-derived perfusion biofilm model. J Breath Res. (2012) 6:016001. doi: 10.1088/1752-7155/6/1/016001

162. Tait E, Perry JD, Stanforth SP, Dean JR. Identification of volatile organic compounds produced by bacteria using Hs-spme-Gc-Ms. J Chromatogr Sci. (2014) 52:363-73. doi: 10.1093/chromsci/bmt042

163. Taylor B, Greenman J. Modelling The effects of $\mathrm{Ph}$ on tongue biofilm using a sorbarod biofilm perfusion system. J Breath Res. (2010) 4:017107. doi: 10.1088/1752-7155/4/1/017107

164. Dawkins LE, Kimber CF, Doig M, Feyerabend C, Corcoran O. Selftitration by experienced e-cigarette users: blood nicotine delivery and subjective effects. Psychopharmacology. (2016) 233:2933-41. doi: $10.1007 /$ s00213-016-4338-2

Conflict of Interest: The authors are employees of Philip Morris International.

Publisher's Note: All claims expressed in this article are solely those of the authors and do not necessarily represent those of their affiliated organizations, or those of the publisher, the editors and the reviewers. Any product that may be evaluated in this article, or claim that may be made by its manufacturer, is not guaranteed or endorsed by the publisher.

Copyright (c) 2021 Zanetti, Zivkovic Semren, Battey, Guy, Ivanov, van der Plas and Hoeng. This is an open-access article distributed under the terms of the Creative Commons Attribution License (CC BY). The use, distribution or reproduction in other forums is permitted, provided the original author(s) and the copyright owner(s) are credited and that the original publication in this journal is cited, in accordance with accepted academic practice. No use, distribution or reproduction is permitted which does not comply with these terms. 